Article

\title{
Synthesis, Inhibitory Effects on Nitric Oxide and Structure- Activity Relationships of a Glycosphingolipid from the Marine Sponge Aplysinella rhax and Its Analogues
}

\author{
Yuzo Fujita ${ }^{1}$, Naohiro Ohshima ${ }^{1}$, Ai Hasegawa ${ }^{1}$, Frank Schweizer ${ }^{2}$, Tadahiro Takeda ${ }^{1}$, \\ Fumiyuki Kiuchi ${ }^{1}$ and Noriyasu Hada ${ }^{1, *}$
}

1 Faculty of Pharmacy, Keio University, 1-5-30 Shibakoen, Minato-ku, Tokyo 105-8512, Japan

2 Department of Chemistry and Medical Microbiology, University of Manitoba, Winnipeg, Manitoba, R3T 2N2, Canada

* Author to whom correspondence should be addressed; E-Mail: hada-nr@pha.keio.ac.jp;

Tel.: +81-3-5400-2666; Fax: + 81-3-5400-2556.

Received: 9 December 2010; in revised form: 29 December 2010 / Accepted: 14 January 2011 / Published: 17 January 2011

\begin{abstract}
The novel glycosphingolipid, $\beta$-D-GalNAc $p(1 \rightarrow 4)[\alpha-\mathrm{D}-\mathrm{Fuc} p(1 \rightarrow 3)]-\beta$-DGlcNAc $p(1 \rightarrow)$ Cer $(\mathbf{A})$, isolated from the marine sponge Aplysinella rhax has a unique structure, with D-fucose and $N$-acetyl-D-galactosamine moieties attached to a reducing-end $N$-acetyl-D-glucosamine through an $\alpha 1 \rightarrow 3$ and $\beta 1 \rightarrow 4$ linkage, respectively. We synthesized glycolipid 1 and some non-natural di- and trisaccharide analogues 2-6 containing a D-fucose residue. Among these compounds, the natural type showed the most potent nitric oxide (NO) production inhibitory activity against LPS-induced J774.1 cells. Our results indicate that both the presence of a D-Fucol-3GlcNAc-linkage and the ceramide aglycon portion are crucial for optimal NO inhibition.
\end{abstract}

Keywords: glycosphingolipid; Aplysinella rhax; D-fucose; nitric oxide

\section{Introduction}

Carbohydrates in the form of glycoconjugates, for example glycoproteins, glycolipids and proteoglycans, play an important role in many intracellular and extracellular events including cell-cell 
adhesion, cell differentiation, signal transduction, cancer metastasis and immune responses [1]. The majority of these studies have focused on higher animals and relatively little is known about the functions of glycoconjugates in lower animals [2]. In order to study the biological properties of glycans in glycoconjugates, over the past decade we have synthesized novel glycolipid and glycoprotein derivatives found in various invertebrates [3-12]. Organic synthesis is a powerful method to explore structure activity relationships by providing access to large amounts of homogeneous and structurally defined oligosaccharides including not only natural compounds, but also non-natural compounds [13]. Recently, Zollo et al. isolated and characterized a novel neutral glycosphingolipid (A, Figure 1) from the marine sponge Aplysinella rhax which features a D-fucose and an $N$-acetyl-Dgalactosamine attached to a reducing-end $N$-acetyl-D-glucosamine through a $\alpha 1 \rightarrow 3$ and a $\beta 1 \rightarrow 4$ linkages, respectively [14]. This was the first report on glycolipids containing D-fucose. Furthermore, these glycolipids have been found to exhibit significant inhibitory activity on LPS-induced nitric oxide (NO) release by J774.1 macrophages. In order to study the structure-activity relationships of these compounds inhibiting NO release, we previously reported the synthesis of $\beta$-D-GalNAc $p(1 \rightarrow 4)[\alpha-D-$ Fuc $p(1 \rightarrow 3)]-\beta-D-G l c N A c p(1 \rightarrow)$ aglycon trisaccharide analogues, containing a 2-branched fatty alkyl residue and a 2-(trimethylsilyl)ethyl (TMS-Et) residue, respectively [6]. Moreover, biological evaluation of these novel glycosphingolipid analogues using an LPS-induced NO release assay demonstrated that the presence of D-fucose is crucial for the NO inhibitory effect, while structural modifications at the aglycon moiety appeared to have little to no effect on LPS-induced NO release [6]. In this study, we describe for the first time the total synthesis of glycosphingolipid $\mathbf{1}$ and its structural analogues 3-6 to elucidate the structure activity relationships on LPS-induced NO production in more detail (Figure 1).

Figure 1. Target glycosphingolipid and the analogue compounds

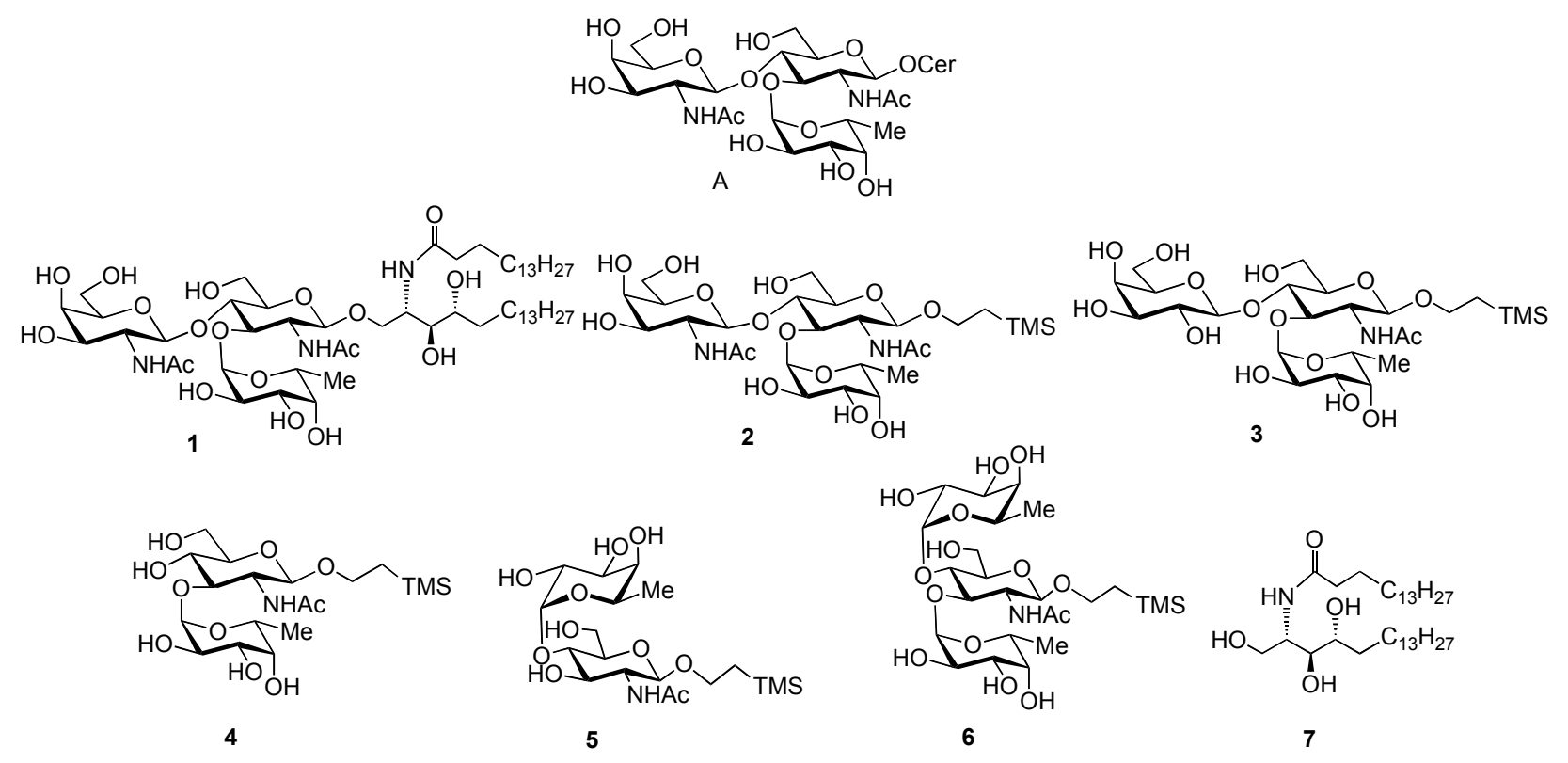

2-(Trimethylsilyl)ethyl $\beta$-D-galactopyranosyl-( $1 \rightarrow 4)$-[ $\alpha$-D-fucopyranosyl-( $1 \rightarrow 3)]-2$-acetamido-2deoxy- $\beta$-D-glucopyranoside (3) was selected to explore how the presence of a terminal $\beta$-D-galacto- 
pyranosyl linkage instead of a 2-acetamido-2-deoxy- $\beta$-D-galactopyranosyl linkage affects the biological effect. Disaccharide-based regioisomers $\mathbf{4}$ and $\mathbf{5}$ were selected to explore differences in the connectivity of the $\alpha$-D-fucopyranosyl moiety to the- $\beta$-D-GlcNAc portion while trisaccharide $\mathbf{6}$ was chosen to study the effect of two $\alpha$-D-fucopyranosyl linkages linked to the core -D-GlcNAc moiety. The NO-inhibitory affect of commercially available ceramide 7 and known trisaccharide 2 was included in these experiments for comparison.

\section{Results and Discussion}

\subsection{Chemical synthesis}

Synthesis of glycosphingolipid 1: Glycosylation of phytoceramide acceptor 9 [15] with the glycosyl imidate 8 [6] was carried out in the presence of trimethylsilyl trifluoromethanesulfonate (TMSOTf) [16] and $4 \AA$ molecular sieves (MS4 $\AA$ ) to obtain the desired glycolipid derivative $\mathbf{1 0}$ in $33 \%$ yield with complete $\beta$-steroselectivity. Deprotection of the Troc group was achieved with $\mathrm{Zn}$ in a mixture containing acetic anhydride and acetic acid, followed by catalytic hydrogenolysis over $10 \% \mathrm{Pd} / \mathrm{C}$ in $\mathrm{MeOH} / \mathrm{THF}$ to provide 11 in 47\% yield. Deacetylation of 11 using Zemplén conditions and purification by column chromatography on Sephadex LH-20 afforded target glycolipid 1 quantitatively (Scheme 1).

Scheme 1. Synthesis of glycosphingolipid 1.
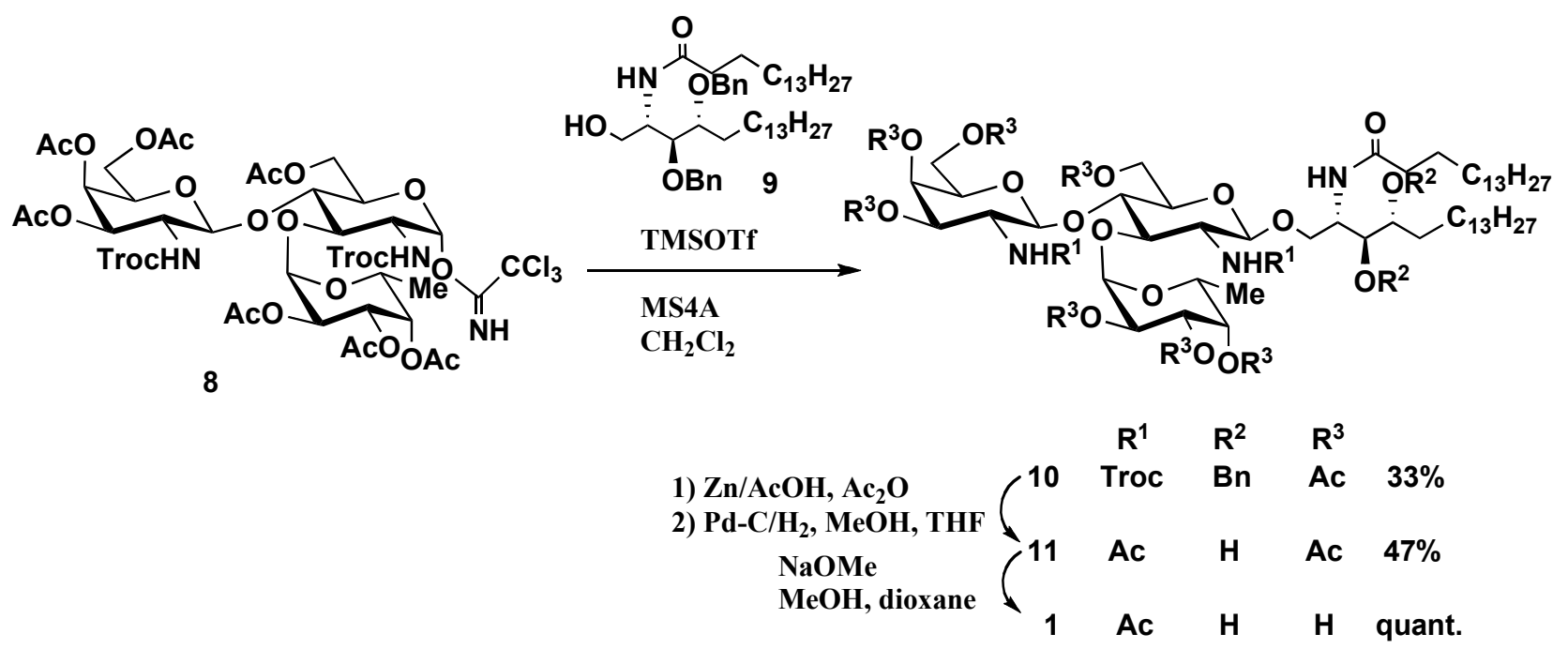

Syntheses of oligosaccharides 3-6: Glycosylation of known disaccharide acceptor 12 [3] with the known D-fucopyranosyl donor 13 [6] in the presence of $\mathrm{N}$-iodosuccinimide (NIS), trifluoromethanesulfonic acid (TfOH) [17] and MS4 $\AA$ in dichloromethane provided the desired $\alpha$-glycoside 14 in $88 \%$ yield with complete $\alpha$-stereoselectivity. The newly formed $\alpha$-glycosidic linkage was confirmed by ${ }^{1} \mathrm{H}-\mathrm{NMR}$ spectroscopy. The anomeric proton of the fucose moiety in $\mathbf{1 4}$ appeared at $4.85 \mathrm{ppm}$ as a doublet with a homonuclear proton-proton coupling constant of $3.7 \mathrm{~Hz}(\mathrm{H}-1$ of Fuc, $\delta=4.85 \mathrm{ppm}$, $J_{\mathrm{H} 1, \mathrm{H} 2}=3.7 \mathrm{~Hz}$ ). Deprotection of the Troc group in 14 was achieved with $\mathrm{Zn}$ in a mixture containing acetic anhydride and acetic acid, followed by catalytic hydrogenolysis over $10 \% \mathrm{Pd}-\mathrm{C}$ in $\mathrm{MeOH}$ and 
acetylation to provide 15. Zemplén deacetylation and purification by column chromatography on Sephadex LH-20 produced trisaccharide 3 quantitatively (Scheme 2).

Scheme 2. Synthesis of oligosaccharide 3.

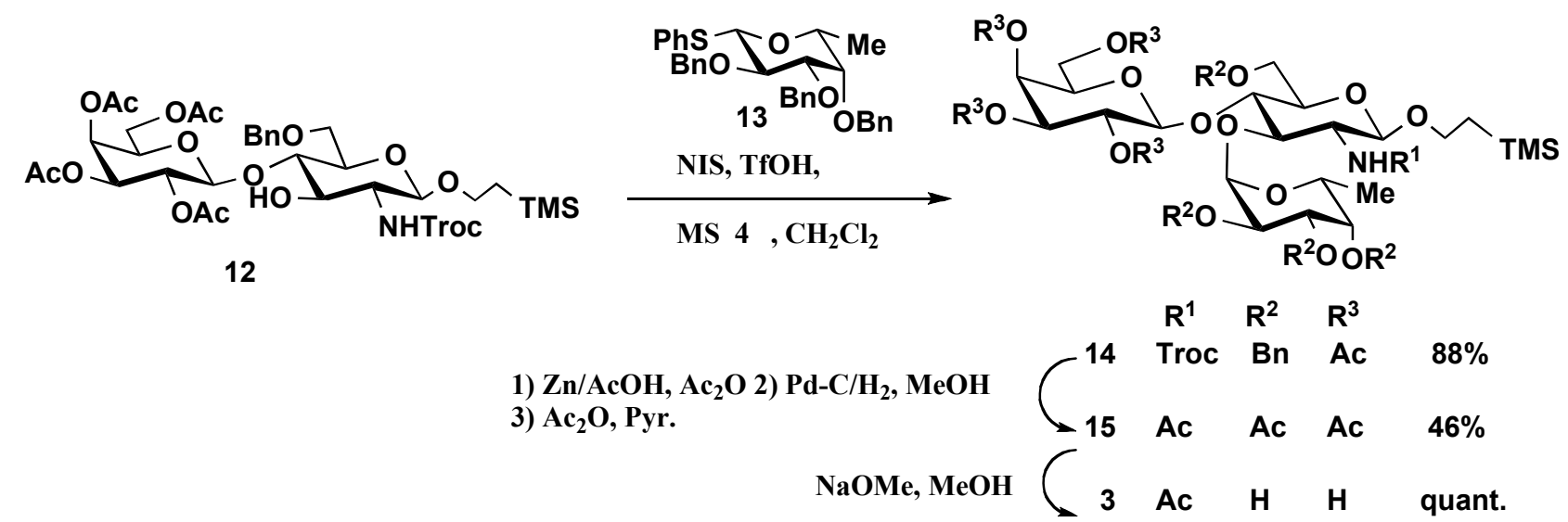

The synthesis of disaccharides $\mathbf{4}$ and $\mathbf{5}$ and trisaccharide $\mathbf{6}$ is outlined in Schemes 3-5. Glycosylation of known glycosyl acceptors 16, 19 [6] and 22 [18] with the D-fucopyranosyl donor 13 in the presence of NIS, TfOH and MS4 $\AA$ in dichloromethane gave the desired $\alpha$-glycosides 17 (68\%), 20 (78\%) and the trisaccharide $23(42 \%)$ with complete $\alpha$-steroselectivity, respectively. The newly formed $\alpha$ glycosidic linkage was confirmed by ${ }^{1} \mathrm{H}-\mathrm{NMR}$ spectroscopy. The Troc-protecting group of 17 was converted into an acetamido group by reduction with $\mathrm{Zn}-\mathrm{AcOH}$ followed by debenzylidenation and debenzylation with catalytic hydrogenolysis over $10 \% \mathrm{Pd} / \mathrm{C}$ in $\mathrm{MeOH}-\mathrm{AcOH}$ and acetylation to afford 18 in $44 \%$ yield. Finally, standard deacetylation and purification by column chromatography on Sephadex LH-20 furnished disaccharide 4 in $86 \%$ yield (Scheme 3).

Scheme 3. Synthesis of oligosaccharide 4.

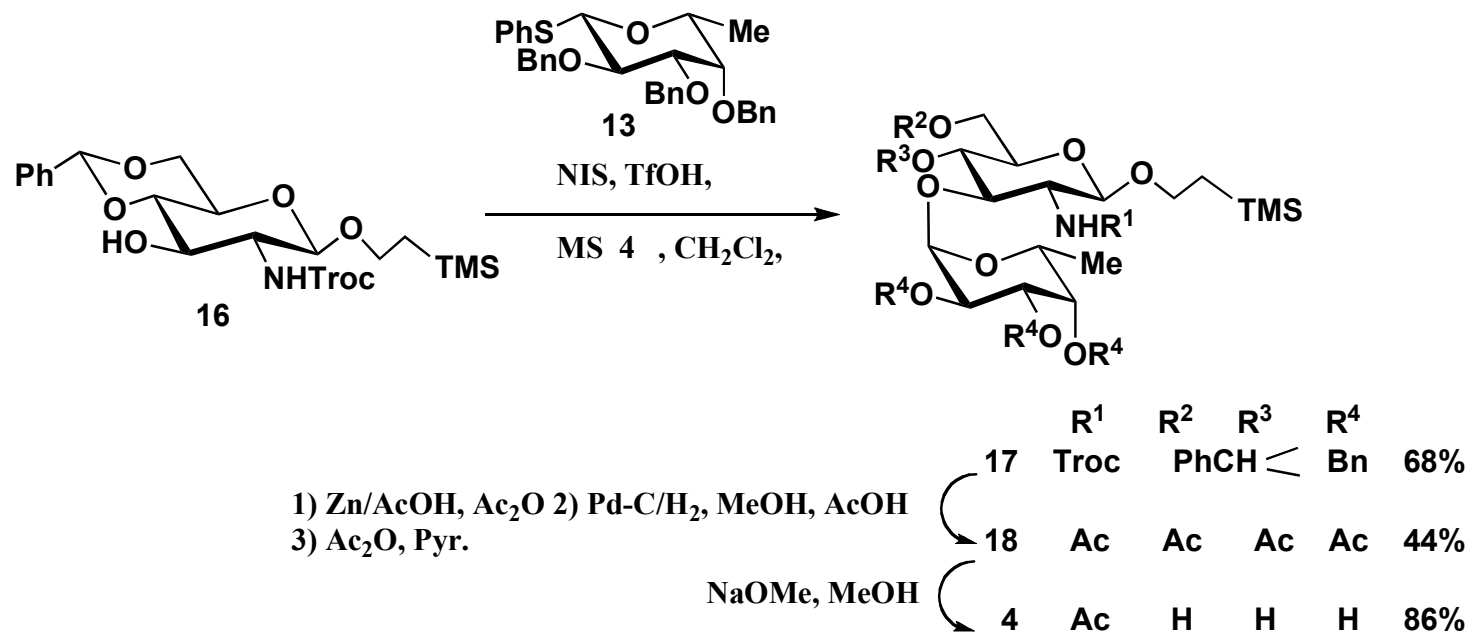

Disaccharide 5 was synthesized from the disaccharide 20 in a six steps deblocking/blocking procedure (Scheme 4). At first, the chloroacetyl protecting group in $\mathbf{2 0}$ was deblocked with thiourea in an ethanol/pyridine solvent mixture before conversion of the Troc group into an acetamido group using 
standard conditions. Debenzylation using catalytic hydrogenolysis followed by acetylation provided protected disaccharide 21 in $45 \%$ yield which was deprotected using standard conditions to provide disaccharide 5 (Scheme 4).

Scheme 4. Synthesis of oligosaccharide 5

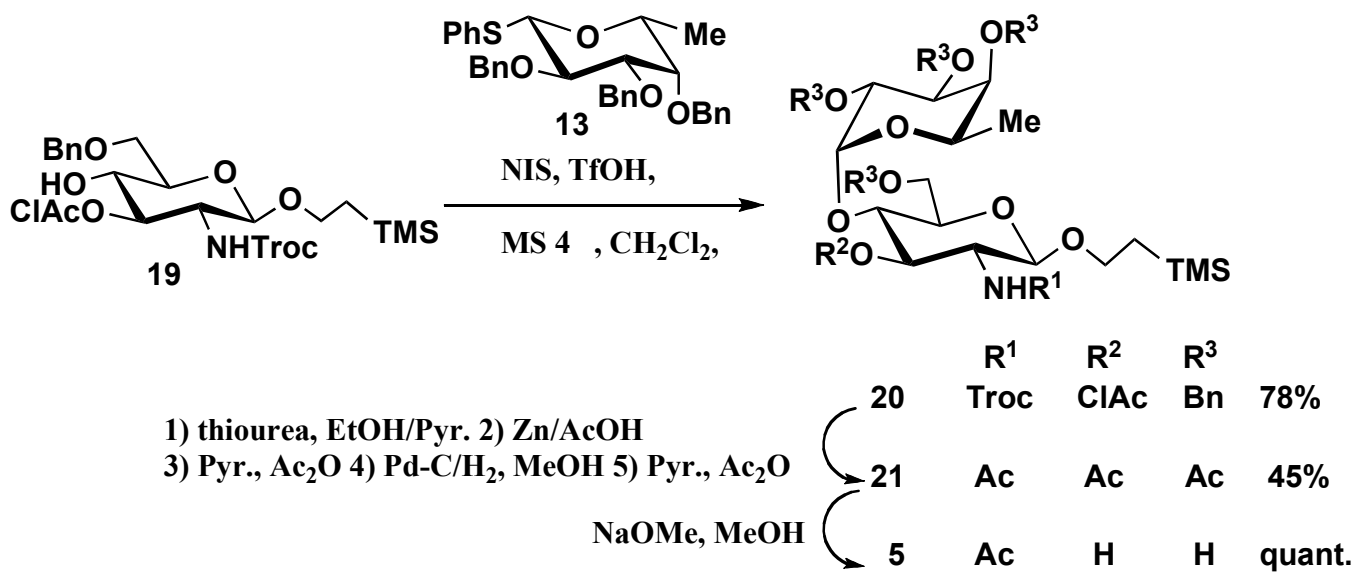

The remaining trisaccharide $\mathbf{6}$ was prepared from protected trisaccharide $\mathbf{2 3}$ in a five steps procedure. Initially, the phthalimido-protecting group of $\mathbf{2 3}$ was removed using hydrazine monohydrate in ethanol followed by standard acetylation, debenzylation by catalytic hydrogenation over $10 \% \mathrm{Pd}-\mathrm{C}$ in $\mathrm{MeOH}-\mathrm{THF}$ and acetylation to provide peracetylated trisaccharide 24 in $47 \%$ yield. Finally, standard deacetylation and purification by column chromatography on Sephadex LH-20 provided disaccharide 6 (Scheme 5). Oligosaccharide 2 was prepared according to a procedure previously reported by us [6].

Scheme 5. Synthesis of oligosaccharide 6

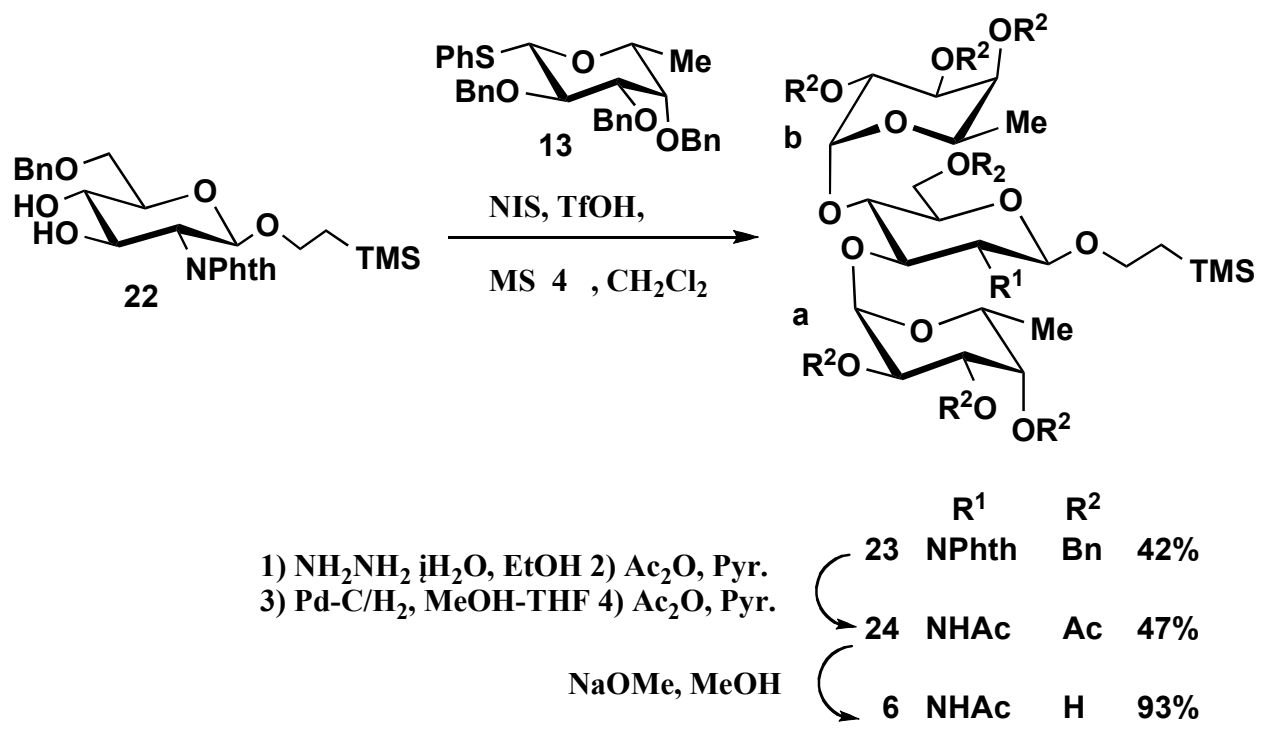




\subsection{Inhibitory Effects of Synthetic Compounds on NO Production}

The synthetic compounds were evaluated for their ability to inhibit nitric oxide (NO) production by LPS-induced macrophage-like J774.1 cells [19] (Figure 2). NO, a short living mediator is synthesized by a family of enzymes termed NO-synthase. Two types of NOS are recognized: constitutive isoforms and inducible isoforms (iNOS). iNOS is regulated by inflammatory mediators (LPS, cytokines) and the excessive production of NO by iNOS has been implicated in the pathogenesis of the inflammatory response [14]. The glycolipid 1 showed comparable NO inhibitory activity in high concentration (100 $\mu \mathrm{M})$ to $\mathrm{N}^{\mathrm{G}}$-monomethyl-L-arginine (L-NMMA) used as the positive control. Related compounds having the common D-Fuco1-3GlcNAc structure (i.e. 2, 3 and 4) also showed significant inhibitory activity resulting in a $20 \%$ reduction of NO release at $50 \mu \mathrm{M}$ and $100 \mu \mathrm{M}$ concentrations. However, very little or no inhibition of NO release were seen at these concentrations for disaccharide $\mathbf{5}$ and trisaccharide $\mathbf{6}$ bearing an unnatural D-Fuc $\alpha 1-4$ GlcNAc linkage. Interestingly, glycosphingolipid $\mathbf{1}$ showed stronger activity than $\mathbf{2}$, suggesting that the ceramide-based aglycon contributes to the inhibition of NO release more efficiently than a 2-(trimethylsilyl) ethyl-based aglycon. Moreover, commercial ceramide 7 showed inhibitory activity at higher concentration $(100 \mu \mathrm{M})$. However, the activity of ceramide is strongly enhanced by glycosylation to the trisaccharide $\beta$-D-GalNAc $p(1 \rightarrow 4)[\alpha-$ D-Fuc $p(1 \rightarrow 3)]-\beta$-D-GlcNAc indicating that both the trisaccharide and ceramide-based aglycon portion of the glycosphingolipid contribute to the inhibition of cellular nitric oxide release.

Figure 2. Inhibitory effects on NO production in LPS-activated J774.1 cells of compounds 1-7. Each data represents the mean \pm SD for quadruplet experimentals. P: Positive control (L-NMMA), $50 \mu \mathrm{M}$.

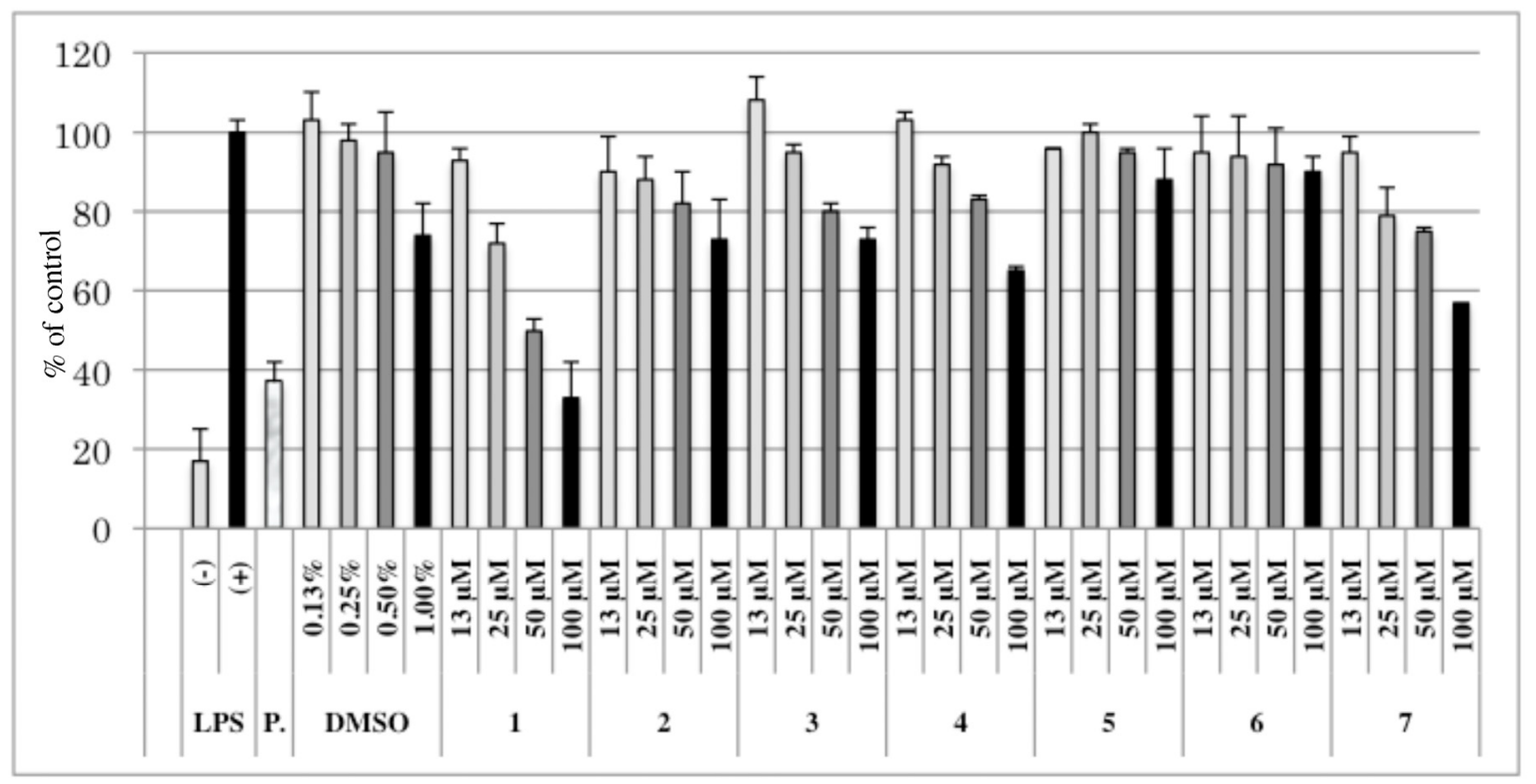

Sample $(\mu \mathrm{M})$ 


\section{Experimental}

\subsection{General}

Optical rotations were measured with a Jasco P-1020 digital polarimeter. ${ }^{1} \mathrm{H}$ - and ${ }^{13} \mathrm{C}-\mathrm{NMR}$ spectra were recorded with JMN A500 and ECP 600 FT NMR spectrometers with $\mathrm{Me}_{4} \mathrm{Si}$ as the internal standard for solutions in $\mathrm{CDCl}_{3}$ and $\mathrm{CD}_{3} \mathrm{OD}$. MALDI-TOFMS was recorded on an Applied Biosystems Voyager DE RP mass spectrometer. High-resolution mass spectra were recorded on a JEOL JMS-700 under FAB conditions. TLC was performed on Silica Gel 60 F254 (E. Merck) with detection by quenching of UV fluorescence and by charring with $10 \% \mathrm{H}_{2} \mathrm{SO}_{4}$. Column chromatography was carried out on Silica Gel 60 (E. Merck). The compounds 3,4,6-Tri-O-acetyl-2deoxy-2-(2,2,2-trichloroethoxycarbonylamino)- $\beta$-D-galactopyranosyl-( $1 \rightarrow 4)$-[2,3,4-tri- $O$-acetyl- $\alpha$-Dfucopyranosyl-( $1 \rightarrow 3)]$ - 6-O-acetyl-2-deoxy-2-(2,2,2-trichloroethoxycarbonylamino)-D-glucopyranosyl trichloroacetimidate (8) [6], 2-(trimethylsilyl)ethyl 2,3,4,6-tetra- $O$-acetyl- $\beta$-D-galactopyranosyl$(1 \rightarrow 4)-6-O$-benzyl-2-deoxy-2-(2,2,2-trichloroethoxycarbonylamino)- $\beta$-D-glucopyranoside (12) [3], phenyl 2,3,4-tri-O-benzyl-1-thio- $\beta$-D-fucopyranoside (13) [6], 2-(Trimethylsilyl)ethyl 4,6-O-benzylidene-2-deoxy-2-(2,2,2-trichloroethoxycarbonylamino)- $\beta$-D-glucopyranoside (16) [6], 2-(trimethylsilyl)ethyl 6-O-benzyl-3-O-chloroacetyl-2-deoxy-2-(2,2,2-trichloroethoxycarbonylamino)- $\beta$-D-glucopyranoside (19) [6] and 2-(trimethylsilyl)ethyl 6-O-benzyl-2-deoxy-2-phthalimide- $\beta$-D-glucopyranoside (22) [18] were prepared as reported. Benzylceramide 9 was prepared by the conventional four-steps procedure [15] from phytosphingosine, which was purchased from Degussa (The Netherlands).

3,4,6-Tri-O-acetyl-2-deoxy-2-(2,2,2-trichloroethoxycarbonylamino)- $\beta$-D-galactopyranosyl-( $1 \rightarrow 4)$ [2,3,4-tri-O-acetyl- $\alpha$-D-fucopyranosyl-(1 $\rightarrow 3)]-6-O$-acetyl-2-deoxy-2-(2,2,2-trichloroethoxycarbonylamino)- $\beta$-D-glucopyranosyl-( $(\rightarrow 1)$ - $(2 S, 3 S, 4 R)-3$,4-di-O-benzyl-2-hexadecanamido-octadecane-3,4-diol (10). Four $\AA$ molecular sieves $(250 \mathrm{mg})$ were added to a solution of 8 (21 mg, $16.5 \mu \mathrm{mol})$ and $(2 S, 3 S, 4 R)$-3-O-benzoyl-2-hexadecanamido-4-octa-decene-1,3-diol $9(24 \mathrm{mg}, 30.0 \mu \mathrm{mol})$ in dry $\mathrm{CH}_{2} \mathrm{Cl}_{2}(0.5 \mathrm{~mL})$ and the mixture was stirred for $16 \mathrm{~h}$ at room temperature, then cooled to $0{ }^{\circ} \mathrm{C}$. TMSOTf ( $3 \mu \mathrm{L}, 0.01 \mathrm{mmol})$ was added, and the mixture was stirred for $1 \mathrm{~h}$ at $0{ }^{\circ} \mathrm{C}$, then neutralized with $\mathrm{Et}_{3} \mathrm{~N}$. The solids were filtered off and washed with $\mathrm{CHCl}_{3}$. The combined filtrate and washings were successively washed with water, dried $\left(\mathrm{MgSO}_{4}\right)$, and concentrated. The product was purified by silica gel column chromatography using 3:1 toluene-EtOAc as eluent to give $\mathbf{1 0}(10 \mathrm{mg}, 33 \%)$. [ $\alpha]_{\mathrm{D}}{ }^{23}$ $=+18.2^{\circ}\left(c_{1.0}, \mathrm{CHCl}_{3}\right)$; ${ }^{1} \mathrm{H}-\mathrm{NMR}\left(500 \mathrm{MHz}, \mathrm{CDCl}_{3}\right): \delta 4.94\left(\mathrm{~d}, 1 \mathrm{H}, J_{1,2}=3.7 \mathrm{~Hz}, \mathrm{H}-1\right.$ of fuc), 4.50 (br. $\mathrm{d}, 1 \mathrm{H}, \mathrm{H}-1$ of GlcNAc), 4.34 (br. s, 1H, H-1, of GalNAc). MALDI-TOFMS: Calcd for $\mathrm{C}_{86} \mathrm{H}_{129} \mathrm{Cl}_{6} \mathrm{~N}_{3} \mathrm{O}_{27} \mathrm{Na}[\mathrm{M}+\mathrm{Na}]^{+}: m / z$ 1868.7 Found: 1869.4.

2-Acetamido-3,4,6-tri-O-acetyl-2-deoxy- $\beta$-D-galactopyranosyl- $(1 \rightarrow 4)$-[2,3,4-tri-O-acetyl- $\alpha$-D-fucopyranosyl-( $1 \rightarrow 3)$ ]-2-acetamido-6-O-acetyl-2-deoxy- $\beta$-D-glucopyranosyl- $(1 \rightarrow 1)-(2 S, 3 S, 4 R)$-hexadecanamido-octadecane-3,4-di-ol (11). To a solution of $\mathbf{1 0}(31 \mathrm{mg}, 16.8 \mu \mathrm{mol})$ in acetic anhydride $(2$ $\mathrm{mL})$ and $\mathrm{AcOH}(2 \mathrm{~mL})$ was added zinc powder $(100 \mathrm{mg})$. The reaction mixture was stirred for $16 \mathrm{~h}$ at room temperature. After completion of the reaction, the solids were filtered off and the filtrate was 
concentrated with toluene. The solution of the product and $\mathrm{Pd} / \mathrm{C}(10 \%, 100 \mathrm{mg})$ in $1: 1 \mathrm{MeOH} / \mathrm{THF}$ $\left(2.0 \mathrm{~mL}\right.$ ) was stirred for $16 \mathrm{~h}$ at room temperature under $\mathrm{H}_{2}$, then filtered and concentrated. The product was purified by silica gel column chromatography using 2:1 toluene acetone as eluent to give 11 as an amorphous powder $(11 \mathrm{mg}, 47 \%)$. $[\alpha]_{\mathrm{D}}{ }^{23}=+5.3^{\circ}\left(c 0.7, \mathrm{CHCl}_{3}\right) ;{ }^{1} \mathrm{H}-\mathrm{NMR}\left(500 \mathrm{MHz}, \mathrm{CDCl}_{3}\right)$ : $\delta 5.15$ (d, $1 \mathrm{H}, J_{1,2}=3.7 \mathrm{~Hz}, \mathrm{H}-1$ of fuc), 4.33 (br. d, $1 \mathrm{H}, \mathrm{H}-1$ of GlcNAc), 4.30 (br. s, 1H, H-1, of GalNAc). MALDI-TOFMS: Calcd for $\mathrm{C}_{70} \mathrm{H}_{119} \mathrm{~N}_{3} \mathrm{O}_{25} \mathrm{Na}[\mathrm{M}+\mathrm{Na}]^{+}: \mathrm{m} / z$ 1424.8 Found: 1424.5 .

2-Acetamido-2-deoxy- $\beta$-D-galactopyranosyl- $(1 \rightarrow 4)$-[ $\alpha$-D-fucopyranosyl- $(1 \rightarrow 3)]$-2-acetamido-2deoxy- $\beta$-D-glucopyranosyl-( $(\rightarrow 1)$-(2S,3S,4R)-hexadecanamido-octadecane-3,4-di-ol $\quad(\mathbf{1}) . \quad$ To a solution of $11(11 \mathrm{mg}, 7.8 \mu \mathrm{mol})$ in $\mathrm{MeOH}(2 \mathrm{~mL})$ was added dioxane $(2 \mathrm{~mL})$ and $\mathrm{NaOMe}(25 \mathrm{mg})$ at $40{ }^{\circ} \mathrm{C}$. The mixture was stirred for $2 \mathrm{~h}$ and then neutralized with Amberlite IR $120\left[\mathrm{H}^{+}\right]$. The mixture was filtered and concentrated. The product was purified by Sephadex LH-20 column chromatography in 1:1 $\mathrm{CHCl}_{3}-\mathrm{MeOH}$ to give 1 as white solid (10 mg, quant.). $[\alpha]_{\mathrm{D}}{ }^{25}+17.0\left(c=0.06,1: 1 \mathrm{CHCl}_{3}-\mathrm{MeOH}\right)$. ${ }^{1} \mathrm{H}-\mathrm{NMR}\left(500 \mathrm{MHz}, 1: 1 \mathrm{CDCl}_{3}-\mathrm{CD}_{3} \mathrm{OD}\right.$ ): $\delta 5.13$ (d, 1H, $J=3.7 \mathrm{~Hz}, \mathrm{H}-1$ of Fuc), 4.62 (d, $1 \mathrm{H}, J=8.3 \mathrm{~Hz}$, H-1 of GlcNAc), 4.32 (d, 1H, d, $1 \mathrm{H}, J=8.0 \mathrm{~Hz}, \mathrm{H}-1$ of GalNAc). MALDI-TOFMS: Calcd for $\mathrm{C}_{56} \mathrm{H}_{105} \mathrm{~N}_{3} \mathrm{O}_{18} \mathrm{Na}: m / z$ 1130.7 Found: $1130.4[\mathrm{M}+\mathrm{Na}]^{+}$. HR-FABMS: Calcd for $\mathrm{C}_{56} \mathrm{H}_{105} \mathrm{~N}_{3} \mathrm{O}_{18} \mathrm{Na}: m / z$ 1130.7291. Found $m / z 1130.7257[\mathrm{M}+\mathrm{Na}]^{+}$.

2-(Trimethylsilyl)ethyl $\quad$ 2,3,4,6-tetra-O-acetyl- $\beta$-D-galactopyranosyl-( $1 \rightarrow 4)$-[2,3,4-tri-O-benzyl- $\alpha$ - $D$ fucopyranosyl-(1 $\rightarrow 3)]$-6-O-benzyl-2-deoxy-2-(2,2,2-trichloroethoxy- $\quad$ carbonylamino)- $\beta$-D-glucopyranoside (14). To a solution of $12(99 \mathrm{mg}, 0.11 \mathrm{mmol})$ and $13(89 \mathrm{mg}, 0.17 \mathrm{mmol})$ in dry $\mathrm{CH}_{2} \mathrm{Cl}_{2}$ $(1.5 \mathrm{~mL})$ was added powdered MS $4 \AA(200 \mathrm{mg})$, and the mixture was stirred for $2 \mathrm{~h}$ at room temperature, then cooled to $-60{ }^{\circ} \mathrm{C}$. NIS $(57 \mathrm{mg}, 0.03 \mathrm{mmol})$ and $\mathrm{TfOH}(1.5 \mu \mathrm{L}, 0.01 \mathrm{mmol})$ were added to the mixture, which was stirred for $3 \mathrm{~h}$ at $-60{ }^{\circ} \mathrm{C}$, then neutralized with $\mathrm{Et}_{3} \mathrm{~N}$. The solids were filtered off and washed with $\mathrm{CHCl}_{3}$. The combined filtrate and washings were successively washed with aq $\mathrm{Na}_{2} \mathrm{~S}_{2} \mathrm{O}_{3}$ and water, dried $\left(\mathrm{MgSO}_{4}\right)$, and concentrated. The product was purified by silica gel column chromatography using 3:1 hexane-EtOAc as eluent to give $14(128 \mathrm{mg}, 88 \%)$. $[\alpha]_{\mathrm{D}}{ }^{24}+20.4(c$ 0.7, $\left.\mathrm{CHCl}_{3}\right) ;{ }^{1} \mathrm{H}-\mathrm{NMR}\left(500 \mathrm{MHz}, \mathrm{CDCl}_{3}\right): \delta 7.28-7.14(\mathrm{~m}, 20 \mathrm{H}, 4 \mathrm{Ph}), 5.74(\mathrm{~d}, 1 \mathrm{H}, \mathrm{NH}), 5.26(\mathrm{~d}, 1 \mathrm{H}$, H-4 of Gal), 5.11 (t, 1H, H-2 of Gal), 4.92-4.84 (m, 2H, H-3 of Gal, benzylmethylene), 4.85 (d, 1H, $J_{1,2}=3.7 \mathrm{~Hz}, \mathrm{H}-1$ of Fuc), 4.75-4.54 (m, 7H, benzylmethylene x 5, $\left.\underline{\mathrm{C}}_{2} \mathrm{CCl}_{3}\right), 4.40\left(\mathrm{~d}, 1 \mathrm{H}, J_{1,2}=7.3 \mathrm{~Hz}\right.$, H-1 of GlcNAc), 4.38 (d, 1H, $J_{1,2}=7.9 \mathrm{~Hz}, \mathrm{H}-1$ of Gal), 4.27 (dd, 2H, benzylmethylene x 2), 4.06-4.02 (m, 2H, H-6a of GlcNAc, H-5 of Fuc), 3.97-3.75 (m, 9H, H-2, H-3, H-6b of GlcNAc, H-5, H-6 of Gal, H-2, H-3 of Fuc, $\left.\underline{\mathrm{CH}}_{2} \mathrm{CH}_{2} \mathrm{Si}\left(\mathrm{CH}_{3}\right)_{3}\right)$, 3.66-3.62 (m, 3H, H-4, H-5 of GlcNAc, H-4 of Fuc), 3.38-3.32 (m, $1 \mathrm{H}, \underline{\mathrm{C}}_{2} \mathrm{CH}_{2} \mathrm{Si}\left(\mathrm{CH}_{3}\right)_{3}$ ), 2.07-1.87 (m, 12H, $\left.\underline{\mathrm{C}}_{3} \mathrm{CO} \times 4\right), 1.09$ (d, 3H, H-6 of Fuc), 0.88-0.73 (m, $\left.2 \mathrm{H}, \mathrm{CH}_{2} \underline{\mathrm{C}}_{2} \mathrm{Si}\left(\mathrm{CH}_{3}\right)_{3}\right),-0.09$ (s, 9H, $\left.\mathrm{Si}\left(\mathrm{CH}_{3}\right)_{3}\right) ;{ }^{13} \mathrm{C}-\mathrm{NMR}\left(125 \mathrm{MHz}, \mathrm{CDCl}_{3}\right): \delta 170.2,170.0,154.2$, 139.0, 138.9, 138.7, 138.3, 128.4, 128.23, 128.20, 127.8, 127.74, 127.65, 127.59, 127.5, 127.3, 100.2 (C-1 of GlcNAc), 100.1 (C-1 of Gal), 99.3 (C-1 of Fuc), 95.8, 79.5, 77.8, 76.4, 76.3, 75.6, 74.8, 74.6, 74.1, 73.5, 73.2, 72.9, 71.0, 70.4, 69.0, 67.4, 66.8, 66.7, 61.1, 53.6, 29.7, 20.8, 20.62, 20.57, 18.2, 16.5, -1.4 $\left(\mathrm{Si}\left(\mathrm{CH}_{3}\right)_{3}\right)$; MALDI-TOFMS: Calcd for $\mathrm{C}_{62} \mathrm{H}_{78} \mathrm{Cl}_{3} \mathrm{NO}_{20} \mathrm{SiNa}: \mathrm{m} / z$ 1312.4 Found: 1312.9 $[\mathrm{M}+\mathrm{Na}]^{+}$. 
2-(Trimethylsilyl)ethyl $\quad 2,3,4,6$-tetra-O-acetyl- $\beta$-D-galactopyranosyl-(1 $\rightarrow 4)$-[2,3,4-tri-O-acetyl- $\alpha$ - $D$ -

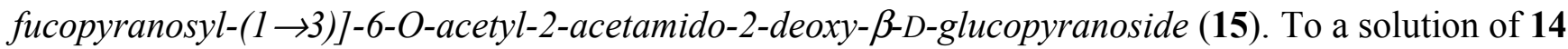
$(107 \mathrm{mg}, 0.08 \mathrm{mmol})$ in acetic anhydride $(6 \mathrm{~mL})$ and $\mathrm{AcOH}(6 \mathrm{~mL})$ was added zinc powder $(150 \mathrm{mg})$. The reaction mixture was stirred for $12 \mathrm{~h}$ at $40{ }^{\circ} \mathrm{C}$. After completion of the reaction, the solids were filtered off and the filtrate was concentrated with toluene. The solution of the product and $\mathrm{Pd} / \mathrm{C}(10 \%$, $100 \mathrm{mg}$ ) in $\mathrm{MeOH}(2.0 \mathrm{~mL})$ was stirred for $16 \mathrm{~h}$ at room temperature under $\mathrm{H}_{2}$, then filtered and concentrated. The residue was acetylated with acetic anhydride $(2 \mathrm{~mL})$ in pyridine $(3 \mathrm{~mL})$ for $16 \mathrm{~h}$ at room temperature. The reaction mixture was poured into ice-water and extracted with $\mathrm{CHCl}_{3}$. The extract was washed sequentially with $5 \% \mathrm{HCl}$, aq $\mathrm{NaHCO}_{3}$ and water, dried $\left(\mathrm{MgSO}_{4}\right)$, and concentrated. The product was purified by silica gel column chromatography using 5:1 toluene-acetone as eluent to give $15(37 \mathrm{mg}, 46 \%)$ as an amorphous powder. $[\alpha]_{\mathrm{D}}{ }^{24}+11.8\left(c 0.7, \mathrm{CHCl}_{3}\right) ;{ }^{1} \mathrm{H}-\mathrm{NMR}$ $\left(500 \mathrm{MHz}, \mathrm{CDCl}_{3}\right): \delta 6.47(\mathrm{~d}, 1 \mathrm{H}, \mathrm{NH}), 5.36(\mathrm{~d}, 1 \mathrm{H}, \mathrm{H}-4$ of Gal), 5.23-5.21 (m, 2H, H-2 of Gal, H-4 of Fuc), 5.10-5.00 (m, 3H, H-3 of Gal, H-2, H-3 of Fuc), 5.08 (d, 1H, $J_{1,2}=3.7$ Hz, H-1 of Fuc), 4.57 (dd, 1H, H-6a of Gal), 4.52 (d, 1H, $J_{1,2}=7.9$ Hz, H-1 of Gal), 4.42 (dd, 1H, H-5 of Fuc), 4.37 (d, 1H, $J_{1,2}=7.9 \mathrm{~Hz}, \mathrm{H}-1$ of GlcNAc), 4.33 (dd, 1H, H-6b of Gal), 4.24 (br d, 1H, H-2 of GlcNAc), 4.09 (d, 2H, H-6 of GlcNAc), 3.93-3.85 (m, 4H, H-3, H-4 of GlcNAc, H-5 of Gal, $\left.\underline{\mathrm{C}}_{2} \mathrm{CH}_{2} \mathrm{Si}\left(\mathrm{CH}_{3}\right)_{3}\right), 3.69$ (s, $1 \mathrm{H}$, $\mathrm{H}-5$ of GlcNAc), 2.18-1.81 (m, 27H, $\underline{\mathrm{C}}_{3} \mathrm{CO} \times$ 9), 1.13 (d, 3H, H-6 of Fuc), 0.98-0.80 (m, 2H, $\left.\mathrm{CH}_{2} \underline{\mathrm{C}}_{2} \mathrm{Si}\left(\mathrm{CH}_{3}\right)_{3}\right),-0.02$ (s, 9H, $\left.\mathrm{Si}\left(\mathrm{CH}_{3}\right)_{3}\right) ;{ }^{13} \mathrm{C}-\mathrm{NMR}\left(125 \mathrm{MHz}, \mathrm{CDCl}_{3}\right): \delta 170.9,170.7,170.5$, 170.3, 170.2, 170.0, 169.9, 169.5, 99.5 (C-1 of Gal), 99.4 (C-1 of GlcNAc), 97.3 (C-1 of Fuc), 73.4, 72.5, 71.8, 71.3, 71.2, 69.9, 68.8, 68.2, 67.9, 66.7, 66.3, 65.7, 64.9, 61.0, 48.5, 22.9, 21.0, 20.9, 20.7, 20.6, 20.52, 20.47, 17.9, 15.7, -1.5 ( $\left.\mathrm{Si}\left(\mathrm{CH}_{3}\right)_{3}\right)$; MALDI-TOFMS: Calcd for $\mathrm{C}_{41} \mathrm{H}_{63} \mathrm{NO}_{23} \mathrm{SiNa}: \mathrm{m} / \mathrm{z}$ 988.3 Found: $988.4[\mathrm{M}+\mathrm{Na}]^{+}$.

2-(Trimethylsilyl)ethyl $\quad \beta$-D-galactopyranosyl- $(1 \rightarrow 4)$-[ $\alpha$-D-fucopyranosyl- $(1 \rightarrow 3)]-2$-acetamido-2deoxy- $\beta$-D-glucopyranoside (3). To a solution of 15 (36 mg, $0.04 \mathrm{mmol})$ in $\mathrm{MeOH}(5 \mathrm{~mL}) \mathrm{NaOMe}(25$ $\mathrm{mg}$ ) was added at $40{ }^{\circ} \mathrm{C}$. The mixture was stirred for $2 \mathrm{~h}$ and then neutralized with Amberlite IR 120 $\left[\mathrm{H}^{+}\right]$. The mixture was filtered and concentrated. The product was purified by Sephadex LH-20 column chromatography in $1: 1 \mathrm{CHCl}_{3}-\mathrm{MeOH}$ to give 5 as white solid $\left(24 \mathrm{mg}\right.$, quant.). $[\alpha]_{\mathrm{D}}{ }^{24}+14.4(c 0.3$, $\mathrm{CH}_{3} \mathrm{OH}$ ); ${ }^{1} \mathrm{H}-\mathrm{NMR}\left(500 \mathrm{MHz}, \mathrm{CD}_{3} \mathrm{OD}\right): \delta 5.12$ (d, $1 \mathrm{H}, J_{1,2}=4.3 \mathrm{~Hz}, \mathrm{H}-1$ of Fuc), $4.42\left(\mathrm{~d}, 1 \mathrm{H}, J_{1,2}=7.9\right.$ $\mathrm{Hz}, \mathrm{H}-1$ of GlcNAc), 4.32 (d, $1 \mathrm{H}, J_{1,2}=7.9 \mathrm{~Hz}, \mathrm{H}-1$ of Gal); ${ }^{13} \mathrm{C}=\mathrm{NMR}\left(125 \mathrm{MHz}, \mathrm{CD}_{3} \mathrm{OD}\right): \delta 173.4$, 104.1 (C-1 of GlcNAc), 102.2 (C-1 of Gal), 102.1 (C-1 of Fuc), 74.8, 73.6, 72.7, 71.5, 70.90, 70.86, $68.5,67.9,62.9,61.1,56.7,30.7,23.5,18.8,16.8,-1.3\left(\mathrm{Si}\left(\mathrm{CH}_{3}\right)_{3}\right)$; MALDI-TOFMS: Calcd for $\mathrm{C}_{25} \mathrm{H}_{47} \mathrm{NO}_{15} \mathrm{SiNa}: m / z$ 652.3 Found: $652.6[\mathrm{M}+\mathrm{Na}]^{+}$. HR-FABMS: Calcd for $\mathrm{C}_{25} \mathrm{H}_{47} \mathrm{NO}_{15} \mathrm{SiNa}: m / z$ 652.2613. Found $m / z 652.2642[\mathrm{M}+\mathrm{Na}]^{+}$.

2-(Trimethylsilyl)ethyl 2,3,4-tri-O-benzyl- $\alpha$-D-fucopyranosyl-(1 $\rightarrow 3)-4,6-O$-benzylidene-2-deoxy-2(2,2,2-trichloroethoxycarbonylamino)- $\beta$-D-glucopyranoside (17). To a solution of $\mathbf{1 6}$ (329 $\mathrm{mg}$, $0.61 \mathrm{mmol})$ and $13(479 \mathrm{mg}, 0.91 \mathrm{mmol})$ in dry $\mathrm{CH}_{2} \mathrm{Cl}_{2}(1.5 \mathrm{~mL})$ was added powdered $4 \AA \mathrm{MS}$ $(800 \mathrm{mg})$, and the mixture was stirred for $2 \mathrm{~h}$ at room temperature, then cooled to $-60{ }^{\circ} \mathrm{C}$. NIS (307 $\mathrm{mg}, 1.37 \mathrm{mmol})$ and $\mathrm{TfOH}(16 \mu \mathrm{L}, 0.18 \mathrm{mmol})$ were added to the mixture, which was stirred for $3 \mathrm{~h}$ at $-60{ }^{\circ} \mathrm{C}$, then neutralized with $\mathrm{Et}_{3} \mathrm{~N}$. The solids were filtered off and washed with $\mathrm{CHCl}_{3}$. The combined filtrate and washings were successively washed with aq $\mathrm{Na}_{2} \mathrm{~S}_{2} \mathrm{O}_{3}$ and water, dried $\left(\mathrm{MgSO}_{4}\right)$, and 
concentrated. The product was purified by silica gel column chromatography using 7:1 hexane-EtOAc as eluent to give 17 (394 mg, 68\%). $[\alpha]_{\mathrm{D}}{ }^{24}+18.9$ (c 2.4, $\left.\mathrm{CHCl}_{3}\right) ;{ }^{1} \mathrm{H}-\mathrm{NMR}\left(500 \mathrm{MHz}, \mathrm{CDCl}_{3}\right)$ : $\delta$ 7.41-6.89 (m, 20H, 4Ph), 5.49 (br s, 1H, H-1 of Fuc), 5.31 (s, 1H, OCHPh), 5.14 (br s, 1H, NH), 4.86-4.75 (m, 3H, benzylmethylene x 2, $\left.\underline{\mathrm{C}}_{2} \mathrm{CCl}_{3}\right), 4.64\left(\mathrm{~d}, 1 \mathrm{H}, J_{1,2}=8.6 \mathrm{~Hz}, \mathrm{H}-1\right.$ of GlcNAc), 4.60 (d, $\left.1 \mathrm{H}, \underline{\mathrm{C}}_{2} \mathrm{CCl}_{3}\right), 4.48(\mathrm{t}, 2 \mathrm{H}$, benzylmethylene x 2), 4.36-4.29 (m, 2H, benzylmethylene x 2), 4.25-4.18 (m, 2H, H-3, H-6a of GlcNAc), 3.96-3.85 (m, 3H, $\mathrm{CH}_{2} \mathrm{CH}_{2} \mathrm{Si}\left(\mathrm{CH}_{3}\right)_{3}, \mathrm{H}-2, \mathrm{H}-5$ of Fuc), 3.81-3.67 (m, $3 \mathrm{H}, \mathrm{H}-4, \mathrm{H}-6 \mathrm{~b}$ of GlcNAc, H-3 of Fuc), 3.52-3.40 (m, 4H, $\mathrm{CH}_{2} \mathrm{CH}_{2} \mathrm{Si}\left(\mathrm{CH}_{3}\right)_{3}, \mathrm{H}-2$, H-5 of GlcNAc, H4 of Fuc), 1.01 (d, 3H, H-6 of Fuc), 0.94-0.79 (m, 2H, $\left.\mathrm{CH}_{2} \mathrm{CH}_{2} \mathrm{Si}\left(\mathrm{CH}_{3}\right)_{3}\right),-0.07$ (s, 9H, $\left.\mathrm{Si}\left(\mathrm{CH}_{3}\right)_{3}\right)$; ${ }^{13} \mathrm{C}-\mathrm{NMR}\left(125 \mathrm{MHz}, \mathrm{CDCl}_{3}\right): \delta 153.7,138.8,138.4,138.2,136.9,129.3,128.5,128.34,128.27,128.1$, 128.0, 127.5, 127.3, 127.1, 126.2, 101.6, 100.8 (C-1 of GlcNAc), 97.0 (C-1 of Fuc), 95.4, 82.5, 78.6, 75.1, 74.8, 74.4, 73.6, 73.3, 71.4, 68.7, 67.6, 67.0, 65.8, 57.0, 29.6, 18.2, 16.7, $-1.5\left(\mathrm{Si}\left(\mathrm{CH}_{3}\right)_{3}\right)$; MALDI-TOFMS: Calcd for $\mathrm{C}_{48} \mathrm{H}_{58} \mathrm{Cl}_{3} \mathrm{NO}_{11} \mathrm{SiNa}[\mathrm{M}+\mathrm{Na}]^{+}: \mathrm{m} / z$ 980.3. Found: 980.1 .

\section{2-(Trimethylsilyl)ethyl 2,3,4-tri-O-acetyl- $\alpha$-D-fucopyranosyl-(1 $\rightarrow 3)$-2-acetamido-4,6-di-O-acetyl-2-} deoxy- $\beta$-D-glucopyranoside (18). To a solution of $17(113 \mathrm{mg}, 0.12 \mathrm{mmol})$ in acetic anhydride $(7 \mathrm{~mL})$ and $\mathrm{AcOH}(7 \mathrm{~mL})$ was added zinc powder $(150 \mathrm{mg})$. The reaction mixture was stirred for $12 \mathrm{~h}$ at $40{ }^{\circ} \mathrm{C}$. After completion of the reaction, the solids were filtrered off and the filtrate was concentrated with toluene. The solution of the product and $\mathrm{Pd} / \mathrm{C}(10 \%, 150 \mathrm{mg})$ in $3: 1 \mathrm{MeOH}-\mathrm{AcOH}(2.0 \mathrm{~mL})$ was stirred for $12 \mathrm{~h}$ at room temperature under $\mathrm{H}_{2}$, then filtered and concentrated. The residue was acetylated with acetic anhydride $(6 \mathrm{~mL})$ in pyridine $(10 \mathrm{~mL})$ for $12 \mathrm{~h}$ at room temperature. The reaction mixture was poured into ice-water and extracted with $\mathrm{CHCl}_{3}$. The extract was washed sequentially with $5 \% \mathrm{HCl}$, aq $\mathrm{NaHCO}_{3}$ and water, dried $\left(\mathrm{MgSO}_{4}\right)$, and concentrated. The product was purified by silica gel column chromatography using 5:1 toluene-acetone as eluent to give $\mathbf{1 8}$ (35 $\mathrm{mg}$, $44 \%)$ as an amorphous powder. $[\alpha]_{\mathrm{D}}{ }^{24}+74.9\left(c 0.3, \mathrm{CHCl}_{3}\right) ;{ }^{1} \mathrm{H}-\mathrm{NMR}\left(500 \mathrm{MHz}, \mathrm{CDCl}_{3}\right): \delta 5.85(\mathrm{~d}$, $1 \mathrm{H}, \mathrm{NH}), 5.25$ (d, 1H, $J_{1,2}=3.7 \mathrm{~Hz}, \mathrm{H}-1$ of Fuc), 5.26-5.23 (m, 2H, H-3, H-4 of Fuc), 5.08 (dd, 1H, H-2 of Fuc), 5.06 (d, 1H, $J_{1,2}=7.9$ Hz H-1 of GlcNAc), 4.97 (dd, 1H, H-4 of GlcNAc), 4.67 (t, 1H, H-3 of GlcNAc), 4.25 (dd, 1H, H-5 of Fuc), 4.14 (dd, 1H, H-6a of GlcNAc), 3.99 (dd, 1H, H-6b of GlcNAc), 3.92-3.87 (m, 1H, $\left.\underline{\mathrm{C}}_{2} \mathrm{CH}_{2} \mathrm{Si}\left(\mathrm{CH}_{3}\right)_{3}\right), 3.61-3.51$ (m, 2H, H-5 of GlcNAc, $\left.\mathrm{C}_{2} \mathrm{CH}_{2} \mathrm{Si}\left(\mathrm{CH}_{3}\right)_{3}\right)$, 3.09-3.04 (m, 1H, H-2 of GlcNAc), 1.08 (d, 3H, H-6 of Fuc), 0.96-0.83 (m, 2H, $\left.\mathrm{CH}_{2} \mathrm{C}_{2} \mathrm{Si}_{2}\left(\mathrm{CH}_{3}\right)_{3}\right)$, $0.02\left(\mathrm{~s}, 9 \mathrm{H}, \mathrm{Si}\left(\mathrm{CH}_{3}\right)_{3}\right) ;{ }^{13} \mathrm{C}-\mathrm{NMR}\left(125 \mathrm{MHz}, \mathrm{CDCl}_{3}\right): \delta 170.7,170.5,98.1$ (C-1 of GlcNAc), $95.8(\mathrm{C}-1$ of Fuc), 73.7, 72.3, 71.5, 71.0, 67.6, 67.4, 67.2, 64.9, 62.5, 58.1, 23.8, 20.9, 20.8, 20.6, 18.1, $16.1-1.4$ $\left(\mathrm{Si}\left(\mathrm{CH}_{3}\right)_{3}\right)$; MALDI-TOFMS: Calcd for $\mathrm{C}_{29} \mathrm{H}_{47} \mathrm{NO}_{15} \mathrm{SiNa}[\mathrm{M}+\mathrm{Na}]^{+}: m / z$ 700.3 Found: 700.5 .

2-(Trimethylsilyl)ethyl $\alpha$-D-fucopyranosyl-(1 $\rightarrow 3)$-2-acetamido-2-deoxy- $\beta$-D-glucopyranoside (4). Compound 4 was prepared from $18(24 \mathrm{mg}, 0.035 \mathrm{mmol})$ by the same method described for preparation of 3 . The product was purified by Sephadex LH-20 column chromatography in 1:1 $\mathrm{CHCl}_{3}-\mathrm{MeOH}$ to give 4 as white solid $(14 \mathrm{mg}, 86 \%)$. $[\alpha]_{\mathrm{D}}{ }^{24}+52.9\left(c 0.1, \mathrm{CH}_{3} \mathrm{OH}\right) ;{ }^{1} \mathrm{H}-\mathrm{NMR}(500$ $\mathrm{MHz}, \mathrm{CD}_{3} \mathrm{OD}$ ): $\delta 4.93$ (d, $1 \mathrm{H}, J_{1,2}=3.1 \mathrm{~Hz}, \mathrm{H}-1$ of Fuc), 4.30 (d, $1 \mathrm{H}, J_{1,2}=8.5 \mathrm{~Hz} \mathrm{H}-1$ of GlcNAc); ${ }^{13} \mathrm{C}-$ NMR (125 MHz, $\mathrm{CD}_{3} \mathrm{OD}$ ): $\delta$ 173.3, 103.6 (C-1 of GlcNAc), 102.2 (C-1 of Fuc), 86.3, 79.5, 77.4, 73.7, $72.5,71.6,70.8,68.5,67.9,62.6,60.2,55.9,30.7,23.4,18.8,16.9,-1.26\left(\mathrm{Si}\left(\mathrm{CH}_{3}\right)_{3}\right)$; MALDITOFMS: Calcd for $\mathrm{C}_{19} \mathrm{H}_{37} \mathrm{NO}_{10} \mathrm{SiNa}: \mathrm{m} / z$ 490.2 Found: $490.6[\mathrm{M}+\mathrm{Na}]^{+}$. HR-FABMS: Calcd for $\mathrm{C}_{19} \mathrm{H}_{37} \mathrm{NO}_{10} \mathrm{SiNa}: \mathrm{m} / z$ 490.2084. Found $\mathrm{m} / z$ 490.2072 [M+Na] $]^{+}$ 
2-(Trimethylsilyl)ethyl 2,3,4-tri-O-benzyl- $\alpha$-D-fucopyranosyl-(1 $\rightarrow 4)-6$-O-benzyl-3-O-chloroacetyl-2deoxy-2-(2,2,2-trichloroethoxycarbonylamino)- $\beta$-D-glucopyranoside (20). Compound 20 was prepared from 19 (226 $\mathrm{mg}, 0.36 \mathrm{mmol})$ and $13(383 \mathrm{mg}, 0.73 \mathrm{mmol})$ by the same method described for preparation of 17. The product was purified by silica gel column chromatography using10:1 hexaneEtOAc as eluent to give 20 as syrup (296 mg, 78\%). $[\alpha]_{\mathrm{D}}{ }^{24}+11.4\left(c 4.0, \mathrm{CHCl}_{3}\right) ;{ }^{1} \mathrm{H}-\mathrm{NMR}(500 \mathrm{MHz}$, $\left.\mathrm{CDCl}_{3}\right): \delta 7.37-7.10(\mathrm{~m}, 20 \mathrm{H}, 4 \mathrm{Ph}), 5.49(\mathrm{~d}, 1 \mathrm{H}, \mathrm{NH}), 5.22(\mathrm{t}, 1 \mathrm{H}, \mathrm{H}-3$ of GlcNAc), $4.89(\mathrm{~d}, 1 \mathrm{H}$, benzylmethylene), $4.87\left(\mathrm{~d}, 1 \mathrm{H}, J_{1,2}=3.7 \mathrm{~Hz}, \mathrm{H}-1\right.$ of Fuc), 4.76-4.53 (m, 9H, H-4 of Fuc, benzylmethylene $\left.\times 6, \underline{C}_{2} \mathrm{CCl}_{3}\right), 4.50\left(\mathrm{~d}, 1 \mathrm{H}, J_{1,2}=7.3 \mathrm{~Hz}, \mathrm{H}-1\right.$ of GlcNAc), $4.45(\mathrm{~d}, 1 \mathrm{H}$, benzylmethylene), 3.92-3.79 (m, 5H, H-4, 6a of GlcNAc, H-2, 5 of Fuc, $\left.\mathrm{CH}_{2} \mathrm{CH}_{2} \mathrm{Si}\left(\mathrm{CH}_{3}\right)_{3}\right), 3.75-3.62$ (m, 5H, H-2, H-6b of GlcNAc, H-3 of Fuc, $\mathrm{ClC}_{2} \mathrm{CO}$ ), 3.51-3.46 (m, 2H, $\left.\mathrm{C}_{2} \mathrm{CH}_{2} \mathrm{Si}_{(\mathrm{CH}}\right)_{3}, \mathrm{H}-5$ of GlcNAc), 0.97 (d, 3H, H-6 of Fuc), $0.98-0.83$ (m, 2H, $\left.\mathrm{CH}_{2} \mathrm{C}_{2} \mathrm{Si}\left(\mathrm{CH}_{3}\right)_{3}\right),-0.09$ (s, 9H, $\left.\mathrm{Si}\left(\mathrm{CH}_{3}\right)_{3}\right)$;

${ }^{13} \mathrm{C}-\mathrm{NMR}\left(125 \mathrm{MHz}, \mathrm{CDCl}_{3}\right): \delta 167.1,154.1,138.5,138.2,138.1,128.6,128.43,128.36,128.3,128.1$, 127.62, 127.55, 127.47, 127.37, 100.1(C-1 of Fuc), 98.8(C-1 of GlcNAc), 95.5, 78.9, 77.7, 75.6, 74.9, 74.8, 74.6, 74.2, 74.0, 73.3, 73.2, 68.7, 67.6, 67.1, 55.5, 40.8, 18.1, 16.6, $-1.32\left(\mathrm{Si}\left(\mathrm{CH}_{3}\right)_{3}\right)$; MALDITOFMS: Calcd for $\mathrm{C}_{50} \mathrm{H}_{61} \mathrm{Cl}_{4} \mathrm{NO}_{12} \mathrm{SiNa}[\mathrm{M}+\mathrm{Na}]^{+}: \mathrm{m} / z$ 1058.3 Found: 1059.2.

2-(Trimethylsilyl)ethyl 2,3,4-tri-O-acetyl- $\alpha$-D-fucopyranosyl-(1 $\rightarrow 4)$-2-acetamido-3,6-di-O-acetyl-2deoxy- $\beta$-D-glucopyranoside (21). To a solution of $20(296 \mathrm{mg}, 0.29 \mathrm{mmol})$ in EtOH (2.5 mL) was added pyridine $(1.5 \mathrm{~mL})$ and thiourea $(173 \mathrm{mg}, 2.32 \mathrm{mmol})$. The reaction mixture was stirred for $6 \mathrm{~h}$ at $80{ }^{\circ} \mathrm{C}$. The mixture was diluted with $\mathrm{CHCl}_{3}$, washed with aq $5 \% \mathrm{HCl}$, aq $\mathrm{NaHCO}_{3}$ and brine, dried $\left(\mathrm{MgSO}_{4}\right)$ and concentrated. The solution of the residue in $\mathrm{AcOH}(2 \mathrm{~mL})$ was added zinc powder (350 mg). The reaction mixture was stirred for $12 \mathrm{~h}$ at $60{ }^{\circ} \mathrm{C}$. After completion of the reaction, the solids were filtered off and the filtrate was concentrated with toluene. The residue was acetylated with acetic anhydride $(4 \mathrm{~mL})$ in pyridine $(7 \mathrm{~mL})$. The reaction mixture was poured into ice-water and extracted with $\mathrm{CHCl}_{3}$. The extract was washed sequentially with $5 \% \mathrm{HCl}$, aq. $\mathrm{NaHCO}_{3}$ and water, dried $\left(\mathrm{MgSO}_{4}\right)$, and concentrated. The solution of the product in $\mathrm{MeOH}(1.5 \mathrm{~mL})$ and $\mathrm{THF}(0.5 \mathrm{~mL})$ was hydrogenolysed under hydrogen in the presence of $10 \% \mathrm{Pd} / \mathrm{C}(150 \mathrm{mg})$ for $16 \mathrm{~h}$ at room temperature, then filtered and concentrated. The residue was acetylated with acetic anhydride $(3 \mathrm{~mL})$ in pyridine $(5 \mathrm{~mL})$. The reaction mixture was poured into ice-water and extracted with $\mathrm{CHCl}_{3}$. The extract was washed sequentially with $5 \% \mathrm{HCl}$, aq $\mathrm{NaHCO}_{3}$ and water, dried $\left(\mathrm{MgSO}_{4}\right)$, and concentrated. The product was purified by silica gel column chromatography using 5:1 toluene-acetone as eluent to give 21 as an amorphous powder $(86 \mathrm{mg}, 45 \%)$. $[\alpha]_{\mathrm{D}}{ }^{24}+49.6\left(c 0.5, \mathrm{CHCl}_{3}\right) ;{ }^{1} \mathrm{H}-\mathrm{NMR}$ $\left(500 \mathrm{MHz} \mathrm{CDCl}_{3}\right): \delta 5.81(\mathrm{~d}, 1 \mathrm{H}, \mathrm{NH}), 5.34\left(\mathrm{~d}, 1 \mathrm{H}, J_{1,2}=3.7 \mathrm{~Hz}, \mathrm{H}-1\right.$ of Fuc $), 5.22-5.05$ (m, 4H, H-3 of GlCNAc, H-2,H-3, H-4 of Fuc), 4.58 (d, 1H, $J_{1,2}=7.9 \mathrm{~Hz} \mathrm{H}-1$ of GlcNAc), 4.46 (dd, 1H, H-6a of GlcNAc), 4.08-4.01 (m, 2H, H-6b of GlcNAc, H-5 of Fuc), 3.95 (t, 1H, H-4 of GlcNAc), 3.88-3.83 (m, $\left.1 \mathrm{H}, \mathrm{C}_{2} \mathrm{CH}_{2} \mathrm{Si}\left(\mathrm{CH}_{3}\right)_{3}\right), 3.78$ (dd, $1 \mathrm{H}, \mathrm{H}-2$ of GlcNAc), 3.61-3.57 (m, 1H, H-5 of GlcNAc), 3.53-3.48 (m, 1H, $\left.\mathrm{CH}_{2} \mathrm{CH}_{2} \mathrm{Si}\left(\mathrm{CH}_{3}\right)_{3}\right), 2.11-1.82$ (m, 18H, $\left.\underline{\mathrm{C}}_{3} \mathrm{CO} \times 6\right), 1.04$ (d, 3H, H-6 of Fuc), 0.91-0.78 (m, 2H, $\left.\mathrm{CH}_{2} \mathrm{CH}_{2} \mathrm{Si}\left(\mathrm{CH}_{3}\right)_{3}\right),-0.07\left(\mathrm{~s}, 9 \mathrm{H}, \mathrm{Si}\left(\mathrm{CH}_{3}\right)_{3}\right) ;{ }^{13} \mathrm{C}-\mathrm{NMR}\left(125 \mathrm{MHz}, \mathrm{CDCl}_{3}\right): \delta 171.0$, 170.7, 170.5, 170.3, 170.1, 170.0, 99.8 (C-1 of GlcNAc), 96.0 (C-1 of Fuc), 75.5, 72.1, 71.8, 70.9, 67.3, 67.2, 66.9, 65.5, 62.7, 54.6, 29.6, 23.1, 20.9, 20.8, 20.7, 20.6, 20.5, 17.8, 15.8, -1.5 $\left(\mathrm{Si}\left(\mathrm{CH}_{3}\right)_{3}\right)$; MALDI-TOFMS: Calcd for $\mathrm{C}_{29} \mathrm{H}_{47} \mathrm{NO}_{15} \mathrm{SiNa}[\mathrm{M}+\mathrm{Na}]^{+}: \mathrm{m} / z$ 700.3 Found: 700.9 . 
2-(Trimethylsilyl)ethyl $\quad \alpha$-D-fucopyranosyl-( $1 \rightarrow 4)$-2-acetamido-2-deoxy- $\beta$-D-glucopyranoside

Compound 5 was prepared from $21(86 \mathrm{mg}, 0.13 \mathrm{mmol})$ by the same method described for preparation of 3. The product was purified by Sephadex LH-20 column chromatography in $1: 1 \mathrm{CHCl}_{3}-\mathrm{MeOH}$ to give 5 as white solid (61 mg, quant.). $[\alpha]_{\mathrm{D}}{ }^{24}+33.9\left(c 0.3, \mathrm{CH}_{3} \mathrm{OH}\right) ;{ }^{1} \mathrm{H}-\mathrm{NMR}\left(500 \mathrm{MHz}, \mathrm{CD}_{3} \mathrm{OD}\right): \delta$ $4.98\left(\mathrm{~d}, 1 \mathrm{H}, J_{1,2}=3.7 \mathrm{~Hz}, \mathrm{H}-1\right.$ of Fuc), 4.32 (d, 1H, $J_{1,2}=7.9 \mathrm{~Hz} \mathrm{H}-1$ of GlcNAc); ${ }^{13} \mathrm{C}-\mathrm{NMR}(125 \mathrm{MHz}$, $\mathrm{CD}_{3} \mathrm{OD}$ ): $\delta$ 173.5, 103.5 (C-1 of Fuc), 102.0 (C-1 of GlcNAc), 82.2, 76.9, 75.9, 73.5, 71.7, 70.6, 68.6, 67.9, 62.5, 56.8, 30.7, 23.0, 18.8, 16.7, -1.3 (Si( (CH3) $\left.)_{3}\right)$; MALDI-TOFMS: Calcd for $\mathrm{C}_{19} \mathrm{H}_{37} \mathrm{NO}_{10} \mathrm{SiNa}$ : $m / z$ 490.2 Found: 491.0 [M+Na] $]^{+}$. HR-FABMS: Calcd for $\mathrm{C}_{19} \mathrm{H}_{37} \mathrm{NO}_{10} \mathrm{SiNa}: m / z$ 490.2084. Found $m / z$ $490.2062[\mathrm{M}+\mathrm{Na}]^{+}$.

\section{2-(Trimethylsilyl)ethyl 2,3,4-tri-O-benzyl- $\alpha$-D-fucopyranosyl-(1 $\rightarrow 3)$-[2,3,4-tri-O-benzyl- $\alpha$-D-fuco-}

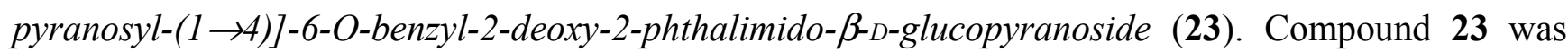
prepared from $22(89 \mathrm{mg}, 0.18 \mathrm{mmol})$ and $13(757 \mathrm{mg}, 1.44 \mathrm{mmol})$ by the same method described for preparation of $\mathbf{1 4}$. The product was purified by silica gel column chromatography using 10:1 hexaneEtOAc as eluent to give 23 as syrup (99 mg, 42\%). $[\alpha]_{\mathrm{D}}{ }^{24}+48.3\left(c 1.2, \mathrm{CHCl}_{3}\right) ;{ }^{1} \mathrm{H}-\mathrm{NMR}(600 \mathrm{MHz}$, $\left.\mathrm{CDCl}_{3}\right): \delta 7.90-7.26(\mathrm{~m}, 39 \mathrm{H}$, NPhth, $8 \mathrm{Ph}), 6.20\left(\mathrm{~d}, 1 \mathrm{H}, J_{1,2}=3.6 \mathrm{~Hz}, \mathrm{H}-1\right.$ of Fuc b), 5.19 (d, 2H, $J_{1,2}=8.5 \mathrm{~Hz} \mathrm{H}-1$ of GlcNAc, $J_{1,2}=4.4 \mathrm{~Hz} \mathrm{H}-1$ of Fuc a), 5.07 (d, 1H, benzylmethylene), 5.01 (dd, 1H, $\mathrm{H}-3$ of GlcNAc), 4.93-4.88(m, 3H, benzylmethylene x 3), 4.79-4.66 (m, 8H, benzylmethylene $x$ 8), $4.62-4.58(\mathrm{~m}, 2 \mathrm{H}$, benzylmethylene x 2), 4.41 (dd, 1H, H-2 of GlcNAc), 4.18-4.13 (m, 2H, H-4 of GlcNAc, H-2 of Fuc b), 4.10 (dd, 1H,H-3 of Fuc a), 4.07-3.99 (m, 2H, $\underline{\mathrm{C}}_{2} \mathrm{CH}_{2} \mathrm{Si}\left(\mathrm{CH}_{3}\right)_{3}$, H-5 of Fuc b), 3.97-3.84 (m, 6H, H-5, H-6 of GlcNAc, H-2, H-5 of Fuc a, H-3 of Fuc b), 3.63-3.57 (m, 2H, H-4 of Fuc b, $\underline{\mathrm{C}}_{2} \mathrm{CH}_{2} \mathrm{Si}\left(\mathrm{CH}_{3}\right)_{3}$ ), 3.47(br.d, $1 \mathrm{H}, \mathrm{H}-4$ of Fuc a), 1.19 (d, 3H, H-6 of Fuc b) 0.95 (d, 3H, H-6 of Fuc a, ), 0.93-0.81 (m, 2H, $\left.\mathrm{CH}_{2} \mathrm{C}_{2}{ }_{2} \mathrm{Si}\left(\mathrm{CH}_{3}\right)_{3}\right),-0.01$ (s, 9H, $\left.\mathrm{Si}\left(\mathrm{CH}_{3}\right)_{3}\right) ;{ }^{13} \mathrm{C}-\mathrm{NMR}(150 \mathrm{MHz}$, $\left.\mathrm{CDCl}_{3}\right): \delta 139.1,138.7,138.52,138.50,138.3,133.8,128.3,128.23,128.18,128.12,128.05,128.03$, 127.93, 127.87, 127.7, 127.6, 127.5, 127.42, 127.37, 127.35, 127.28, 127.23, 127.1, 123.1, 169.3, 9, 97.6 (C-1 of GlcNAc), 97.5 (C-1 of Fuc a), 95.0 (C-1 of Fuc b), 78.8, 78.7, 78.4, 78.1, 78.0, 76.4, 76.3, 74.9, 74.6, 73.5, 73.3, 73.1, 73.0, 72.9, 72.8, 69.7, 67.7, 67.0, 66.7, 56.3, 29.7, 17.8, 16.6, 15.8, -1.5 $\left(\mathrm{Si}\left(\mathrm{CH}_{3}\right)_{3}\right)$; MALDI-TOFMS: Calcd for $\mathrm{C}_{80} \mathrm{H}_{89} \mathrm{NO}_{15} \mathrm{SiNa}[\mathrm{M}+\mathrm{Na}]^{+}: m / z$ 1354.6 Found: 1354.8 .

\section{2-(Trimethylsilyl)ethyl 2,3,4-tri-O-acetyl- $\alpha$-D-fucopyranosyl-(1 $\rightarrow 3)-[2,3,4$-tri-O-acetyl- $\alpha$-D-fuco-}

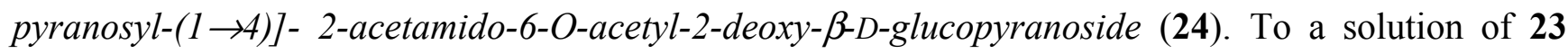
$(60 \mathrm{mg}, 0.05 \mathrm{mmol}$ in EtOH $(10 \mathrm{~mL}))$ was added hydrazine monohydrate $(3.3 \mathrm{~mL}, 0.07 \mathrm{mmol})$. The reaction mixture was refluxed for $3 \mathrm{~h}$, then concentrated. The residue was acetylated with $\mathrm{Ac}_{2} \mathrm{O}(3 \mathrm{~mL})$ in pyridine $(5 \mathrm{~mL})$. The mixture was poured into ice-water and extracted with $\mathrm{CHCl}_{3}$. The extract was washed sequentially with $5 \% \mathrm{HCl}$, aq $\mathrm{NaHCO}_{3}$ and water, dried $\left(\mathrm{MgSO}_{4}\right)$, and concentrated. The solution of the product in $\mathrm{MeOH}(1 \mathrm{~mL})$ and THF $(1 \mathrm{~mL})$ was hydrogenolysed under hydrogen in the presence of $10 \% \mathrm{Pd} / \mathrm{C}(100 \mathrm{mg})$ for $15 \mathrm{~h}$ at room temperature, then filtered and concentrated. The residue was acetylated with acetic anhydride $(5 \mathrm{~mL})$ in pyridine $(7 \mathrm{~mL})$. The reaction mixture was poured into ice-water and extracted with $\mathrm{CHCl}_{3}$. The extract was washed sequentially with $5 \% \mathrm{HCl}$, aq $\mathrm{NaHCO}_{3}$ and water, dried $\left(\mathrm{MgSO}_{4}\right)$, and concentrated. The product was purified by silica gel column chromatography using 9:1 toluene-acetone as eluent to give 24 as syrup (19 $\mathrm{mg}, 47 \%)$. $[\alpha]_{\mathrm{D}}{ }^{24}+75.2(c$ $0.5 \mathrm{CHCl}_{3}$ ); ${ }^{1} \mathrm{H}-\mathrm{NMR}\left(500 \mathrm{MHz}, \mathrm{CDCl}_{3}\right): \delta 6.43(\mathrm{~d}, 1 \mathrm{H}, \mathrm{NH}), 5.28$ (dd, $1 \mathrm{H}, \mathrm{H}-3$ of Fuc b), 5.23-5.18 
(m, 3H, H-3, H-4 of Fuc a, H-4 of Fuc b), 5.13 (d, 1H, $J_{1,2}=3.7$ Hz, H-1 of Fuc b), 5.08-5.03 (m, 2H, H-3 of GlcNAc, H-2 of Fuc b), 5.04 (d, $1 \mathrm{H}, J_{1,2}=9.8 \mathrm{~Hz} \mathrm{H}-1$ of GlcNAc), 4.66 (d, 1H, $J_{1,2}=3.7 \mathrm{~Hz} \mathrm{H}-1$ of Fuc a), 4.52 (dd, 1H, H-6a of GlcNAc), 4.43-4.36 (m, 2H, H-6b of GlcNAc, H-5 of Fuc b), 4.13-4.08 (m, 2H, H-2 of GlcNAc, H-5 of Fuc a), 3.96 (t, 1H, H-5 of GlcNAc), 3.91-3.85 (m, 1H, $\left.\mathrm{C}_{2} \mathrm{CH}_{2} \mathrm{Si}\left(\mathrm{CH}_{3}\right)_{3}\right), 3.60-3.55$ (m, 2H, H-4 of GlcNAc, H-2 of Fuc a), 3.46-3.40 (m, 1H, $\left.\mathrm{C}_{2} \mathrm{CH}_{2} \mathrm{Si}\left(\mathrm{CH}_{3}\right)_{3}\right), 2.13-1.87$ (m, 21H, $\left.\mathrm{CH}_{3} \mathrm{CO}\right) 1.10$ (d, 3H, H-6 of Fuc b) 1.07 (d, 3H, H-6 of Fuc a), 0.95-0.80 (m, 2H, $\left.\mathrm{CH}_{2} \mathrm{CH}_{2} \mathrm{Si}\left(\mathrm{CH}_{3}\right)_{3}\right),-0.03\left(\mathrm{~s}, 9 \mathrm{H}, \mathrm{Si}\left(\mathrm{CH}_{3}\right)_{3}\right) ;{ }^{13} \mathrm{C}-\mathrm{NMR}\left(125 \mathrm{MHz}, \mathrm{CDCl}_{3}\right): \delta 170.5$, 170.43, 170.36, 170.31, 169.9, 169.5, 169.3, 98.5 (C-1 of Fuc a), 98.2 (C-1 of Fuc b), 97.6 (C-1 of GlcNAc), 76.9, 76.8, 76.7, 74.1, 74.0, 73.7, 73.4, 71.2, 70.9, 68.3, 68.00, 67.97, 67.3, 66.5, 65.8, 65.7, $64.5,49.3,29.7,23.4,21.4,20.9,20.7,20.6,18.0,16.0,15.8,15.7,14.1,-1.5\left(\mathrm{Si}\left(\mathrm{CH}_{3}\right)_{3}\right)$; MALDITOFMS: Calcd for $\mathrm{C}_{39} \mathrm{H}_{61} \mathrm{NO}_{21} \mathrm{SiNa}[\mathrm{M}+\mathrm{Na}]^{+}: m / z$ 930.3 Found: 930.5 .

2-(Trimethylsilyl)ethyl $\alpha$-D-fucopyranosyl-(1 $\rightarrow 3)$-[ $\alpha$-D-fucopyranosyl-(1 $\rightarrow 4)]$ - 2-acetamido-2-deoxy$\beta$-D-glucopyranoside (6). Compound 6 was prepared from 24 (16 mg, $0.03 \mathrm{mmol})$ by the same method described for preparation of $\mathbf{3}$. The product was purified by Sephadex LH-20 column chromatography in $1: 1 \mathrm{CHCl}_{3}-\mathrm{MeOH}$ to give 6 as white solid $(10 \mathrm{mg}, 93 \%)$. $[\alpha]_{\mathrm{D}}{ }^{24}+72.2\left(c 0.2 \mathrm{CH}_{3} \mathrm{OH}\right) ;{ }^{1} \mathrm{H}-\mathrm{NMR}$ $\left(600 \mathrm{MHz}, \mathrm{CD}_{3} \mathrm{OD}\right): \delta 4.97$ (d, $1 \mathrm{H}, J_{1,2}=3.9 \mathrm{~Hz} \mathrm{H}-1$ of Fuc b), 4.66 (d, 1H, $J_{1,2}=2.8 \mathrm{~Hz} \mathrm{H}-1$ of Fuc a), $4.38\left(\mathrm{~d}, 1 \mathrm{H}, J_{1,2}=6.1 \mathrm{~Hz} \mathrm{H}-1\right.$ of GlcNAc), -0.09 (s, 9H, $\left.\mathrm{Si}\left(\mathrm{CH}_{3}\right)_{3}\right) ;{ }^{13} \mathrm{C}-\mathrm{NMR}\left(150 \mathrm{MHz}, \mathrm{CD}_{3} \mathrm{OD}\right)$ : $\delta$ 172.8, 101.8 (C-1 of GlcNAc), 101.6 (C-1 of Fuc a), 100.1 (C-1 of Fuc b), 79.3, 78.3, 74.8, 73.7, 73.5, 71.4, 70.1, 69.8, 68.5, 68.3, 67.6, 63.1, 54.7, 27.0, 23.1, 18.9, 16.7, $-1.3\left(\mathrm{Si}\left(\mathrm{CH}_{3}\right)_{3}\right)$; MALDI-TOFMS: Calcd for $\mathrm{C}_{25} \mathrm{H}_{47} \mathrm{NO}_{14} \mathrm{SiNa}: m / z$ 636.3 Found: $636.7[\mathrm{M}+\mathrm{Na}]^{+}$. HR-FABMS: Calcd for $\mathrm{C}_{25} \mathrm{H}_{47} \mathrm{NO}_{14} \mathrm{SiNa}: m / z$ 636.2664. Found $m / z$ 636.2681 [M+Na] $]^{+}$.

\subsection{Nitric Oxide Inhibitory Assay}

J774.1 cells were grown in Dulbecco's Modified Eagle's Medium (DMEM, GIBCO) and cultured at $37^{\circ} \mathrm{C}$ in humidified $5 \% \mathrm{CO}_{2} / 95 \%$ air. The cells were suspended in medium, plated on 96 -well culture plates (Falcon) at a density of $5.0 \times 10^{5}$ cells $/ \mathrm{mL} /$ well, volume of $200 \mu \mathrm{L} /$ well and allowed to adhere for $24 \mathrm{~h}$. Then, the medium was replaced with fresh medium, containing LPS $(1 \mu \mathrm{g} / \mathrm{mL})$ from E. coli (Sigma) and test compounds dissolved in DMSO at various concentrations $(13,25,50,100 \mu \mathrm{M})$ were incubated for $24 \mathrm{~h}$. NO production was determined by measuring the accumulation of nitrite (a stable metabolite of NO) in the culture supernatant using Griess reagent [20]. Briefly, $50 \mu \mathrm{L}$ of the supernatant from incubates were mixed with equal volume of Griess reagent $(1 \%$ sulfanilamide and $0.1 \% N$-1-naphthylenediamine dihydrochloride in $\left.5 \% \mathrm{H}_{3} \mathrm{PO}_{4}\right)$ and were allowed to stand for 10 minutes at room temperature. Absorbance at $550 \mathrm{~nm}$ was measured using a MTP-810 Microplate Reader (Corona Co.). The blank correction was carried out by subtracting the absorbance due to medium from the absorbance reading of each well. The reaction percentage was calculated as follows: $\%$ of control $=[\mathrm{As} / \mathrm{Ac}] \times 100$, where As and Ac are absorbance of a run treated with LPS and a sample, and that treated with LPS alone, respectively. In this assay, $\mathrm{N}^{\mathrm{G}}$-monomethyl-L-arginine (L-NMMA, $\mathrm{IC}_{50} 32.0 \mu \mathrm{M}$ ), a non-selective nitric oxide synthase (NOS) inhibitor, was used as a positive control [21]. 


\section{Conclusions}

We have succeeded for the first time in carrying out the total syntheses of D-fucose-containing glycosphingolipids found in invertebrate species. Both the presence of a D-Fuco1-3GlcNAc-linkage and the ceramide aglycon portion resulted in a significant enhancement of their ability to inhibit NO production by LPS-induced macrophage-like J774.1 cells. The prepared glycolipids are easily-accessible target compounds in the field of carbohydrate chemistry and may serve as chemical probes to explore glycosphingolipid-mediated anti-inflammatory processes in biology and medicine.

\section{Acknowledgements}

This work was supported by a Grant-in-Aid for Scientific Research (No. 19590011) from the Ministry of Education, Culture, Sports, Science and Technology of Japan (MEXT), and the (MEXT) Open Research Center project. The authors are grateful to J. Hada for providing HR-FABMS data.

\section{References and Notes}

1. Seeberger, P. H.; Werz, D. B. Synthesis and medical applications of oligosaccharides. Nature 2007, 446, 1046-1051.

2. Galonic, D. P.; Gin, D. Y. Chemical glycosylation in the synthesis of glycoconjugate antitumour vaccines. Nature 2007, 446, 1000-1007.

3. Itonori, S.; Sugita, M. Glycophylogenetic aspects of lower animals. In Comprehensive Glycoscience; Kamerling, J.P., Ed.; Elsevier Ltd.: Amerstertand, The Netherlands, 2007; Volume 3, pp. 253-284.

4. Kanaya, T.; Yagi, S.; Schweizer, F.; Takeda, T.; Kiuchi, F.; Hada, N. Synthetic studies on glycosphingolipids from Protostomia phyla: synthesis of glycosphingolipids from the parasite Schistosoma mansoni. Chem. Pharm. Bull. 2010, 58, 811-817.

5. Koizumi, A.; Hada, N.; Kaburaki, A.; Yamano, K.; Schweizer, F.; Takeda, T. Synthetic studies on the carbohydrate moiety of the antigen from the parasite Echinococcus multilocularis. Carbohydr. Res. 2009, 344, 856-868.

6. Hada, N.; Shida, Y.; Shimamura, H.; Sonooda, Y.; Kasahara, T.; Sugita, M.; Takeda, T. Synthetic studies on glycosphingolipids from Protostomia phyla: syntheses and biological activities of amphoteric glycolipids containing a phosphocholine residue from the earthworm Pheretima hilgendorfi. Carbohydr. Res. 2008, 343, 2221-2228.

7. Hada, N; Nakashima, T; Shrestha, S. P; Masui, R; Narukawa, Y; Tani, K; Takeda, T. Synthesis and biological activities of glycosphingolipid analogues from marine sponge Aplysinella rhax. Bioorg. Med. Chem. Lett. 2007, 17, 5912-5915.

8. Hada, N.; Sonoda, Y.; Takeda, T. Synthesis of a novel glycosphingolipid from the millipede, Parafontaria laminata armigera and the clusterization of the carbohydrate residue. Carbohydr. Res. 2006, 341, 1341-1352.

9. Yamamura, T.; Hada, N.; Kaburaki, A.; Yamano, K.; Takeda, T. Synthetic studies on glycosphingolipids from Protostomia phyla: total syntheses of glycosphingolipids from the parasite, Echinococcus multilocularis. Carbohydr. Res. 2004, 339, 2749-2759 
10. Ohtsuka, I.; Hada, N.; Sugita, M.; Takeda, T. Synthetic studies on glycosphingolipids from Protostomia phyla: synthesis of arthro-series glycosphingolipids. Carbohydr. Res. 2003, 337, 2037-2047.

11. Ohtsuka, I.; Hada, N.; Ohtaka, H.; Sugita, M.; Takeda, T. Synthetic studies on glycosphingolipids from Protostomia phyla: synthesis of amphoteric glycolipid analogues from the porcine nematode, Ascaris suum. Chem. Pharm. Bull. 2002, 50, 600-604.

12. Hada, N.; Ohtsuka, I.; Sugita, M.; Takeda, T. Synthetic studies on novel fucosylated glycosphingolipids from the millipede, Parafontaria laminata armigera. Tetrahedoron Lett. 2000, 41, 9065-9068.

13. Koester, D. C.; Holkenbrink, A.; Werz, D. B. Recent advances in the synthesis of carbohydrate mimetics. Synthesis 2010, 3217-3242.

14. Borbone, N.; Marino, S. D.; Iorizzi, M.; Zollo, F.; Debitus, C.; Ianaro, A.; Pisano, B. New glycosphingolipids from the marine sponge Aplysinella rhax and their potential as nitric oxide release inhibitions. Eur. J. Org. Chem. 2001, 4651.

15. Xia, C.; Yao, Q.; Schümann, J.; Rossy, E.; Chen, W.; Zhu, L.; Zhang, W.; De Libero, G.; Wang, P.G. Synthesis and biological evaluation of $\alpha$-galactosylceramide (KRN7000) and isoglobotrihexosylceramide (iGb3). Bioorg. Med. Chem. Lett. 2006, 16, 2195-2199.

16. Schmidt, R. R. New methods for the synthesis of glycosides and oligosaccharides - are there alternatives to the Koenigs-Knorr method? [new synthetic methods (56)]. Angew. Chem. Int. Ed. 1986, 25, 212-235.

17. Konradsson, P.; Udodong, U. E.; Fraser-Reid B. Iodonium promoted reactions of disarmed thioglycosides. Tetrahedron Lett. 1990, 31, 4313-4316.

18. Ellervik, U.; Magnusson, G. A high yielding chemical synthesis of sialyl lewis $\mathrm{x}$ tetrasaccharide and lewis $\mathrm{x}$ trisaccharide; examples of regio- and stereodifferentiated glycosylations. J. Org. Chem.1998, 63, 9314-9322.

19. Salvemini, D.; Korbut, R.; Vane, J. NG-Monomethyl-L-arginine inhibits release of a nitric oxidelike substance induced by E. coli lipopolysaccharide in the mouse macrophage cell line, J774. International Congress Series 1990, 897, 267-273.

20. Dirsch, V. M.; Stuppner, H.; Vollmar, A. M. The griess assay: suitable for a bio-guided fractionation of anti-inflammatory plant extracts? Planta Med. 1998, 64, 423-426.

21. Park, K. H.; Park, M. P.; Choi, S. E.; Jeong, M. S.; Kwon, J. H.; Oh, H. M.; Choi, K. H.; Seo, J. S.; Lee, W. M. The Anti-oxidative and anti-inflammatory effects of caffeoyl derivatives from the roots of Aconitum koreanum R. RAYMOND. Biol. Pharm. Bull. 2009, 32, 2029-2033.

(C) 2011 by the authors; licensee MDPI, Basel, Switzerland. This article is an open access article distributed under the terms and conditions of the Creative Commons Attribution license (http://creativecommons.org/licenses/by/3.0/). 